This item was submitted to Loughborough's Research Repository by the author.

Items in Figshare are protected by copyright, with all rights reserved, unless otherwise indicated.

\title{
The role of dissolved oxygen levels on human Mesenchymal Stem Cell culture success, regulatory compliance and therapeutic potential
}

\section{PLEASE CITE THE PUBLISHED VERSION}

https://doi.org/10.1089/scd.2017.0291

\section{PUBLISHER}

(C) Mary Ann Liebert, Inc.

\section{VERSION}

AM (Accepted Manuscript)

\section{PUBLISHER STATEMENT}

This work is made available according to the conditions of the Creative Commons Attribution-NonCommercialNoDerivatives 4.0 International (CC BY-NC-ND 4.0) licence. Full details of this licence are available at: https://creativecommons.org/licenses/by-nc-nd/4.0/

\section{LICENCE}

CC BY-NC-ND 4.0

\section{REPOSITORY RECORD}

Bahsoun, Soukaina, Karen Coopman, Nicholas R. Forsyth, and Liz Akam. 2018. "The Role of Dissolved Oxygen Levels on Human Mesenchymal Stem Cell Culture Success, Regulatory Compliance and Therapeutic Potential". figshare. https://hdl.handle.net/2134/34528. 
The role of dissolved oxygen levels on human Mesenchymal Stem Cell culture success, regulatory compliance and therapeutic potential

Soukaina Bahsoun ${ }^{1}$, Karen Coopman ${ }^{2}$, Nicholas R. Forsyth ${ }^{3}$ and Elizabeth C. Akam ${ }^{1}$

1. School of Sport, Exercise and Health Sciences, Loughborough University, Loughborough, Leicestershire, LE11 3TU, United Kingdom. General telephone: +44 (0)1509 263171

2. Centre for Biological Engineering, Loughborough University, Loughborough, Leicestershire, LE11 3TU, United Kingdom. General telephone: +44 (0)1509 263171

3. Guy Hilton Research Centre, Institute for Science \& Technology in Medicine, Keele University, Thornburrow Drive, Stoke-on-Trent ST4 7QB United Kingdom. General telephone: $+44(0) 1782674988$

Short title - The role of dissolved $\mathrm{O}_{2}$ levels on hMSC culture success

Key words - atmospheric oxygen; dissolved oxygen; human mesenchymal stem cell; hypoxia; mammalian tissue culture; normoxia; oxygen

Corresponding author; Dr Elizabeth Akam, Loughborough University, Loughborough, Leicestershire, LE11 3TU, United Kingdom: Telephone +44 (0)1509 222579: Fax: +44 (0)1509 226301; E mail e.c.akam@lboro.ac.uk

Acknowledgments to Professors Hewitt and Nienow for their ongoing advice and direction and Prof Parker for his time in providing kind and sage guidance on performing and preparing a review for Stem Cells and Development.

Financial support from the Engineering and Physical Research Council (EP/L015072/1), UK and SSEHS, Loughborough University is acknowledged. 
Author Disclosure Statement; The authors declare no potential conflicts of interest.

\section{Abstract}

Most cells in the human body, including human mesenchymal stem cells (hMSCs), have evolved to survive and function in a low, physiological, oxygen $\left(\mathrm{O}_{2}\right)$ environment. Investigators have become increasingly aware of the effects of $\mathrm{O}_{2}$ levels on hMSC biology and culture and are mimicking the natural niche of these cells in vitro to improve cell culture yields. This presents many challenges in relation to hMSC identity and function and in the maintenance of a controlled $\mathrm{O}_{2}$ environment for cell culture. The aim of this review is to discuss a "hMSC checklist" as a guide to establishing which identity and potency assays to implement when studying hMSCs. The checklist includes markers, differentiation potential, proliferation \& growth, attachment \& migration, genomic stability and paracrine activity. Evidence drawn from the current literature demonstrates that low $\mathrm{O}_{2}$ environments could improve most "hMSC checklist" attributes. However, there are substantial inconsistencies around both the terminology and the equipment used in low $\mathrm{O}_{2}$ studies. Therefore, "hypoxia" as a term and as a culture condition are discussed. The biology of short (acute) vs long-term (chronic) hypoxia is considered and a nascent hypothesis to explain the behaviour of hMSCs in long-term hypoxia is presented. It is hoped that by establishing an ongoing discourse and driving towards a regulatory recognisable "hMSC checklist", we may be better able to provide the patient population with safe and efficacious regenerative treatments.

\section{Introduction}

Regenerative medicine is an active area of public health research. The definition of regenerative medicine can be extensive, covering a large spectrum of therapies spanning 
across the generation and use of therapeutic cells to correct aberrant enzymic function, the generation of organic and inorganic scaffolds to promote wound healing, to the production of artificial limbs, joints and organs. Mason and Dunnill suggest a succinct definition including therapies incorporating the use of human cells whereby "Regenerative medicine replaces or regenerates human cells, tissues or organs, to restore or establish normal function” [1].

Stem cells are viewed by many as a primary raw material for the industry of regenerative medicine but even here lies debate around what crucially defines a stem cell (SC)[2,3]. Even on the backdrop of ongoing scientific discussion SCs are clearly a fundamental tool in the field and are presented as a long-term hope in the resolution of treatment refractory health problems. Yet to fully address the potential and hope associated with SC therapies we, as a scientific community, must continue to discuss and define what is sound science and to mean what we say when we report or collate results [3]. It is only then that we will provide the FDA [4,5], other regulatory authorities and above all patients with genuinely hopeful and safe and efficacious treatment(s) [6].

Stem cells commonly come from one of two main sources either being embryonic or adult (somatic) stem cells. Yet whatever the source of the cells and state of the debate around infinite asymmetric division they are commonly categorized by their potential to differentiate into other types of cells on a varying spectrum of potency. Human Mesenchymal Stem Cells (hMSCs) are multipotent SCs, which can be isolated with relative ease from various tissues including bone marrow, umbilical cord, adipose tissue and dental tissues [7]. As well as the relative ease of extraction and supply they can give rise to, minimally, specialized cell types such as osteoblasts, chondrocytes and adipocytes. In addition to their multipotent spectrum hMSCs have widespread immunomodulatory effects [8] as well as an angiogenic induction ability [9]. Taken together these characteristics give hMSCs a high potential of becoming a primary therapeutic option. There are 815 clinical trials listed by the US National Institute of 
Health aiming to assess the effectiveness of MSCs in treating diseases such as Parkinson's, diabetes, liver, kidney and lung diseases as well as cardiovascular, bone and cartilage diseases [10]. Yet to date published clinical data does little to support the advancement of this therapeutic hope [4].

A significant delaying factor in the translation of hMSC therapies into the clinic is their low number in vivo; for example, they constitute about 0.001 to $0.01 \%$ of the bone marrow nucleated cell population [9]. After hMSC isolation there is a requirement for tremendous in vitro expansion to produce a therapeutic dose of cells; estimated at 10 to 50 million hMSC per treatment [11]. This process must be performed without compromising the viability, safety, purity or potency of the cells. The expansion step is challenging and requires a comprehensive understanding of cell culture conditions in order to produce validated therapeutic cells in large quantities.

Human MSC expansion has been studied widely across a variety of equipment types and culture condition combinations. The various cell culture systems available include unilayered T-flasks, multi-layered T-flasks, hyper-stack cell culture vessels, cell factories, different bioreactor types with/without micro-carriers in suspension and manual versus automated systems. In terms of culture conditions, the variation is also extensive and involves serum-free medium [12,13], defined medium [14,15], human platelet lysate as fetal bovine serum replacement [16,17] and various serum (5-20\%) [18] and oxygen levels (0.2-5\%) [19] [18,20-26]. This backdrop is akin to having multiple synthetic routes for the generation of a single drug yet, in that instance as well as here, the ultimate goal from a manufacturing and patient perspective, is to produce a regulatory approved product able to deliver the desired “therapeutic function" with minimal side effects. This review aims to propose a "hMSC checklist” and then to discuss one influencing culture/manufacturing variable for the 
production of therapeutic and regulatory quality hMSCs which is the level of dissolved oxygen $\left(\mathrm{dO}_{2}\right)$ in the medium.

\section{"hMSC checklist" - a proposal to both enhance therapeutic potential and to navigate the regulatory terrain}

Initially, three main criteria were used to define hMSCs; adherence to plastic, fibroblast-like morphology, and the presence of certain surface markers. However, relying solely on these criteria was problematic because they are not exclusive to hMSCs but shared with many primary mammalian cell types such as endothelial cells, fibroblasts, hematopoietic stem cells and B- and T- lymphocytes [27]. In 2006, the International Society for Cellular Therapy (ISCT) described a basic unified guideline on characterizing hMSC which consisted of:

-plastic adherence.

-expression of CD105, CD90 and CD73 with lack of expression of CD45, CD34, CD14 or CD11b, CD79alpha or CD19 and HLA-DR surface molecules.

- ability to differentiate into osteoblasts, adipocytes and chondroblasts in vitro [28].

Since 2006, to date the use of hMSCs has significantly increased [29]. In parallel, the criteria and indicators that can be used to define hMSCs and assess their quality have developed considerably $[29,30]$. By a working consensus in the scientific community these currently include (Refer also Figure 1):

Markers: These have become numerous and include the presence of CD105, CD73, CD90, CD102 and CD124 and absence of CD45, CD34, CD14, CD15 and CD18 (for expanded list see [9,31]). Ongoing discussion in the scientific community may yet widen the list of potential surface phenotypic markers for hMSCs $[29,30]$ as the expression of even an ISCT guided set of surface markers has yet to guarantee hMSC homogeneity. 
Differentiation potential: Human MSCs expanded in vitro are routinely assessed for their ability to differentiate into osteoblasts, adipocytes and chondrocytes. The protocols for inducing these specific linages are well-established and are routinely performed in MSCbased studies [15,22,32,33] assessing MSCs for tri-linage differentiation potential [33-35]. Also the differentiation of hMSCs into neural cells [33] and endothelial cells [36] has been achieved in vitro and the differentiation of hMSCs into cardio-myocytes in vivo and in vitro has also been discussed $[37,38]$. However, the differentiation assays commonly used are qualitative and not easy to quantify thus, making changes in differentiation open to some subjectivity.

Proliferation and growth: This can be evaluated via many methodologies including population doubling levels, population doubling times, cell mean viability, viable cell yield, and expansion yield. It has been demonstrated that hMSC proliferation rate can be enhanced by modifying culture conditions $[11,19,22,24,26]$. In parallel with proliferation rate are the determination of passages, or population doublings, up to which hMSCs can still be used for therapeutic purposes (i.e. before senescence or losing multipotency). The proteins that are more likely to be defected by population expansion are components of the cytoskeleton and those involved in stress response, metabolism, cycle regulation and apoptosis [39]. The number of passages may not be a concern for autologous therapies because usually one to four passages are enough to produce clinically relevant cell numbers [40]. However, for allogeneic banked cells, where an extensive in vitro expansion is required, growth without replicative senescence is an important factor.

Attachment and migration potential: Human MSC attachment and migration are vital for successful therapies. It is well documented that one of the main problems in the transplantation of stem cells in the human body is their loss or their navigation far from the desired therapeutic site, in other words, poor engraftment. MSC are often injected in injured 
tissues where they must adapt to low oxygen and nutrients, oxidative stress and inflammatory and apoptotic signals [41]. This micro-environment affects the MSC's ability to adhere to the extracellular matrix resulting into cell death by anoikis [42]. Attachment and migration assays are established [43-48] and routinely used in hMSC studies but the protocols used can be subject to a high level of variation.

Genomic stability: Long-term hMSC in vitro expansion makes them vulnerable to accumulate genetic defects which may alter the potency of the cells and raise safety concerns. [49,50]. Cell expansion during the manufacturing process may be a cause of replicative stress, chromosomal abnormalities [39], reduced telomerase activity [51] and senescence [52]. Therefore, cells from early passages were recommended to be used in clinical settings $[32,53,54]$. However, there are conflicting reports on genomic stability in MSCs $[55,56]$, suggesting that bone marrow MSCs may remain suitable for cell therapy even after extended ex-vivo expansion and that genomic stability may be a donor dependent variable [57]. A second level of genomic assessment may be a profile for the proteome of hMSCs listing highly expressed proteins involved in different defining aspects of stem cell activity such as metabolism, differentiation and structural components [58].

Paracrine function: This may become central to the assessment of hMSC function as there is growing evidence that in many cases it is not the hMSCs arriving at the site of injury alone which achieves tissue repair, but a significant part of their therapeutic potential relies on the growth factors and cytokines that they secrete (the hMSC secretome [59-63]). Human MSC secreted proteins include fibroblast growth factor 2 (FGF-2), hepatocyte growth factor (HGF) and epidermal growth factor (EGF) [30,64] among others. This secretome profile enables hMSCs to exert paracrine activity in key areas such as tissue regeneration, immunomodulation [65-70], and angiogenic induction [45,71-77], which in turn potentiates their therapeutic application. Although this functional capacity of hMSCs was not originally 
listed in the ISCT 2006 criteria its emerging importance can be seen by the 2014 recommendation by the ISCT to assess human MSC immunomodulatory activity [78] and other ongoing discussions related to functional assay stabilisation for product development $[30,67,79]$. The strengthening of this facet of the "hMSC checklist" via the ISCT suggested assays shows the importance of defining these parameters for regulatory interaction.

It is currently relatively frequent practice to take into consideration the first three criteria (markers, differentiation potential and attachment \& migration) from the "hMSC checklist" in most hMSC-based studies. However when we consider the production of hMSCs in the fastevolving cell therapy industry, cell manufacturing for approved therapies will most probably follow two different routes: “on-site” [80] and “off-the-shelf” [19]. “On-site” or autologous therapies are more likely to be totally processed at the clinic i.e. harvesting, expanding, delivering and if required, storage of cells. In this case, assay implementation and attributes assessment will heavily rely on the nature of the treatment, on the facility and the staff [80]. “Off-the-shelf” or allogeneic therapies are more likely to be manufactured at a large scale, enabling mass production, banking and distributing. In such a setting, the implementation of many of the "hMSC checklist" attributes become even more important to enable product validation and regulatory compliance.

The translation from bench to bedside requires that hMSC efficacy to be proven both in vivo and in vitro. That is why more research and experimentation are required to develop potency assays that can define and quantify, at a regulatory level, hMSC efficacy in all facets especially paracrine effects such as angiogenesis and immunomodulation. While research works to discuss and reduce the inherent variability of these assays it is critical they effectively mimic the physiological niche of the cells to improve in vitro-in vivo correlation. One key culture condition that is suggested to be taken into consideration in developing these assays and in hMSC experimentation in general is low $\mathrm{O}_{2}$ tension. 


\section{Dissolved Oxygen levels in hMSC culture}

The ability of mammalian cells to survive limited $\mathrm{O}_{2}$ is reflective of an earlier evolutionary stage where unicellular organisms were exposed to a low $\mathrm{O}_{2}$ atmosphere [81]. A few human cell types have adapted to ambient atmospheric $21 \% \mathrm{O}_{2}$, such as those found in the lining of the oral cavity, trachea and the lungs; whereas the majority of the others in tissues and organs including stem cells, remained adapted to low $\mathrm{O}_{2}$ supply. This is illustrated by the enhanced proliferation that primary cells, including hMSC [20], display in low $\mathrm{O}_{2}$ environments and the widespread transcriptional alterations low $\mathrm{O}_{2}$ induces via the evolutionarily conserved HIF family of transcription factors [81-84].

Human MSCs reside in tissues such as bone marrow, adipose, articular cartilage, brain, dental, skin and perinatal organs [7] where the levels of $\mathrm{O}_{2}$ are precisely tuned. Inspired air has an $\mathrm{O}_{2}$ concentration of $21 \%$ dropping to approximately $12 \%$ at the alveolar level. As $\mathrm{O}_{2}$ diffuses across the Type I pneumocytes in the lungs it then circulates in the capillaries, complexed to haemoglobin, to reach organs and tissues. $\mathrm{O}_{2}$ concentration drops dramatically to reach approx.1-6\% in the bone marrow, $2-8 \%$ in the adipose tissue and $4-14 \%$ in the heart [85]. This means that hMSC physiological niche is a low $\mathrm{O}_{2}$ environment. In other words, it can be said that the "normal” environment for hMSC is limited in $\mathrm{O}_{2}$ supply.

Due to the variation in oxygen concentrations in the human body it is important to cast light upon the terminology used in cell biology and regenerative medicine with regards to $\mathrm{O}_{2}$. In the past twenty years, it has become more evident that culturing stem cells in conditions like their natural niche or similar to the niche where they are intended to be engrafted is more reliable when drawing conclusions about the cells' potencies. Over the years, the terminology has settled on the use of "normoxic" culture condition when the cells are exposed to $20 \% \mathrm{O}_{2}$ level in culture headspace and the use of "hypoxic" culture condition when the cells are 
exposed to $0.5-10 \% \mathrm{O}_{2}$ levels. According to the medical dictionary, "normoxia” can be defined as: “A state of oxygen normalcy; normal levels of oxygen in tissue or blood” [86] while "hypoxia” can be defined as: “A decrease below normal levels of oxygen in inspired gases, arterial blood, or tissue without reaching anoxia” [87].

From these definitions, taken together with their commonly applied terminology, it becomes clear that confusion and inaccuracy can easily and commonly prevail. Zoran Ivanovic [81] in his article titled "Hypoxia or in situ normoxia: The stem cell paradigm" considered that the term "normoxia” was transferred from physiology to cell biology and to cell culture with scant regard to the prevalence of "low" yet normal $\mathrm{O}_{2}$ level in tissues and that hypoxia itself is often linked to disease. In addition, this oversight goes beyond the terminology itself to include a number of vital biological processes reliant upon a limited $\mathrm{O}_{2}$ supply including erythropoiesis, angiogenesis, brain development, and regulation of gene expression. This historical oversight has resulted in the majority of cell culture being performed in atmospheric $21 \% \mathrm{O}_{2}$ which for virtually all tissues is considered to be a high $\mathrm{O}_{2}$ level or "hyperoxia” (excess supply of $\mathrm{O}_{2}$ ). Rafiq et al. [88] estimated that normoxia referring to a $20 \% \mathrm{O}_{2}$ level in the head space of a cell culture vessel is equivalent to a $100 \% \mathrm{dO}_{2}$ in the medium (physiologically hyperoxic) while hypoxia referring to an $\mathrm{O}_{2}$ level between $0.5 \%$ and $10 \%$ oxygen in the head space is equivalent to $10-25 \% \mathrm{dO}_{2}$ in the medium (approaching physiologically normoxic when referencing 21\% atmospheric oxygen).

To lend clarity to this discussion (to try and "mean what we say" [3]) what follows is an explanation of widely used $\mathrm{O}_{2}$ terminology in relation to the physiochemical properties of oxygen. The amount of $\mathrm{O}_{2}$ is always referred to as a percentage. In particular, the percentage of $\mathrm{O}_{2}$ in the atmosphere, as aforementioned, is about $21 \%$. However, $\mathrm{O}_{2}$ percentage does not always correspond to the $\mathrm{O}_{2}$ concentration which is measured in ppm or mg/L. The correspondence between the percentage and the concentration depends on the altitude which 
subsequently affects $\mathrm{O}_{2}$ partial pressure [89]. Measuring $\mathrm{O}_{2}$ concentration in a cell culture system is complicated because $\mathrm{O}_{2}$ exists in two phases: gaseous in the headspace and dissolved in the liquid media. The concentration of $\mathrm{O}_{2}$ in the two phases is not the same. $\mathrm{O}_{2}$ diffuses from the headspace into the liquid and this diffusion is ruled by several laws including Henry’s law [90] and Fick’s law [91]. Moreover, $\mathrm{O}_{2}$ solubility is affected by several factors including temperature, salinity and pressure. In fact, dissolution reduces with increasing temperature, salinity and pressure. For example, in a hypoxic tissue culture workstation set at $5 \% \mathrm{O}_{2}$ level, a liquid medium can hold a maximum of $\mathrm{X} \mathrm{mg} / \mathrm{L} \mathrm{O}_{2}$ at temperature $\mathrm{T} 1$. At temperature $\mathrm{T} 2$, the same liquid medium at $5 \% \mathrm{O}_{2}$ will hold a maximum of $\mathrm{Y} \mathrm{mg} / \mathrm{L} \mathrm{O}_{2}$. The difference between $\mathrm{X}$ and $\mathrm{Y}$ is of high importance when considering the amount of $\mathrm{O}_{2}$ available for the cells in each scenario (refer Figure 2). Doran [92] explains in great details all the steps involved in calculating the $\mathrm{dO}_{2}$ level in a cell culture system namely fermenters, bioreactors and shake flasks. However, monitoring $\mathrm{dO}_{2}$ in small scale plastic cell culture flasks is less common but methods have been published on how to perform it $[93,94]$.

So, when we come to consider cell culture the following terminology is often used with “normoxia”, referencing a $20 \% \mathrm{O}_{2}$ level in the head space and "hypoxia”, referring to an $\mathrm{O}_{2}$ level between $0.5 \%$ and $10 \% \mathrm{O}_{2}$ in the head space. These terms are broad and only refer to $\mathrm{O}_{2}$ in the gaseous phase without taking into consideration the temperature, salinity, pressure of the liquid phase, cell growth phase, media composition and the subsequent $\mathrm{O}_{2}$ dissolution. Therefore, monitoring $\mathrm{dO}_{2}$ must be one of the main steps when culturing cells in low $\mathrm{O}_{2}$. It is recommended that the terminology used in research articles to describe $\mathrm{O}_{2}$ culture condition is defined early and kept constant.

\section{Inducing hypoxia in an experimental setting}


Environmental hypoxia induction techniques vary hugely among laboratories ranging from home-made systems, hypoxic incubators and chambers to hypoxic workstations [19]. In multi-user facilities using hypoxic incubators prone the cells to periods of re-oxygenation every time the incubator door is opened (i.e. every time flasks are taken out for microscopic examination, medium change or passaging) [95]. This oxygen level fluctuation accompanied by the lack of direct oxygen monitoring in media may lead to unpredicted or conflicting results. Hypoxic workstations remain the current ultimate option for creating and maintaining a low oxygen environment throughout an experiment. These stations are usually equipped with humidity, temperature, oxygen and carbon dioxide controls that are connected to a realtime feedback system. They can be large enough to home a microscope and to host all activities so that flasks are not removed or exposed to ambient air at any point. In terms of hypoxia better experimental designs that allow close oxygen level monitoring and maintenance should enable current literature disparities to be resolved in the move towards a standardized and validated therapeutic product. Indeed, commercial systems are now entering the marketplace which describe the controlled modulation of $\mathrm{dO}_{2}$ within culture media, to desired levels, prior to its use in cell culture. Environmental hypoxia induction techniques (equipment) are still surrounded by various challenges such as cost and stabilisation of low $\mathrm{O}_{2}$ levels throughout experiments (Table 1). Alternatively, chemical induction of hypoxia using mimetic agents such as Cobalt Chloride $\left(\mathrm{CoCl}_{2}\right)$ and Deferoxamine Mesylate (Desferrioxamine; DFO) can be deployed. Both $\mathrm{CoCl}_{2}$ and DFO are chelating agents which act to stabilise Hypoxia Inducible Factor (HIF) at atmospheric oxygen levels. Chemical induction of hypoxia is cheap and easy to perform and circumvents the main limitation of environmental hypoxia, re-oxygenation, but chemical induction of hypoxia has its own limitations as well (Table 1) [96].

\section{Culturing hMSC in hypoxic conditions}


If we accept some of the variation with $\mathrm{O}_{2}$ (detailed above) as the current scientific paradigm and adopt a starting perspective that low $\mathrm{O}_{2}$ reflects the hMSC endogenous environment, we can reflect on a volume of research from recent years (2006 to date) investigating the effect of low $\mathrm{O}_{2}$, in percentage terms, on hMSC performance in culture. There is a mounting evidence that low $\mathrm{O}_{2}$ affects all aspects of hMSC biology listed on the "hMSC checklist" and from the data collated from human cell-based studies it is revealed that environmental hypoxia generally enhances hMSC performance (refer Table(s) 2-7 and Figure 3).

aFrom the data presented in Table 2 it can be concluded that hypoxic culture has no significant effect on hMSC cellular phenotype (defined as defined as the presence of CD105, CD73, CD90 and absence of CD45) regardless of cell source. This conclusion aligned to the tripartite release criteria for MSC-like cellular products, and the physiological hypoxic niche of hMSCs, should enable some confidence that hypoxic culture conditions could become the "norm" for the generation of these cellular and gene therapy (CGT) based products. When examining the effects of hypoxia on hMSC population expansion (Table 5), again the data for hypoxic conditioning is mainly positive showing that hMSC yield is likely to be greater when the cells are cultured, across a number of days, under low $\mathrm{O}_{2}$. Thus, hypoxia would enable a faster, larger-scale manufacturing platform for this CGT product. Hypoxia also appears to generally enhance the ability of implanted hMSCs to migrate which may be essential for certain therapeutic applications [158,159] (Table 4). With respect to favourable hMSC characteristics [98] which are not yet formally required for product authentication, the current literature strongly supports the maintenance of multi-potency [22,24,107,111,123], genetic stability [11,101,103,132] and paracrine activity [98,99,134,135] (refer Tables 6\&7). Table 7, although directed to paracrine activity, indicates the influence of hypoxia upon microRNA (miRNA) release [136,137]. MiRNAs are one of several epigenetic regulators in hMSCs that alter in response to hypoxia and/or oxidative perturbations [160,161]. Epigenetic changes 
produce alterations in gene expression that are not hard coded in the hMSC genome [162], encompassing mechanisms such as such as DNA methylation and histone modification as well as the non-coding RNAs (ncRNAs). Most data support the maintenance of "stemness" by hypoxic epigenetic pathways $[130,163,164]$ and that these hypoxic pathways may involve epigenetic plasticity akin to that identified in a tumour microenvironment $[160,165,166]$. An epigenetic profile desired in a hMSC CGT product has yet to be fully elucidated but as knowledge develops the ambition would be to examine the full effects of hypoxia on the agreed epigenetic genotype.

Despite the high level of accord generated by environmental hypoxia on the "hMSC checklist”, differentiation potential is still seen as varied in low $\mathrm{O}_{2}$ (Table 2). It is generally accepted that low $\mathrm{O}_{2}$ promotes chondrogenic differentiation via hypoxic downregulation of RUNX2 [167]. Yet bidirectional variability exists with respect to osteogenic and adipogenic differentiation, which may be reflective of the different $\mathrm{O}_{2}$ concentrations in in vivo niches for these different cells, the subsequent variation exerted on epigenetic regulation of differentiation, variability at the assay level or donor mediated variability [103,168-170]. Although hypoxia's effect on hMSC differentiation potentially introduces variation to the ISCT criteria and the "hMSC checklist", there is an accumulating body of evidence that hMSC's paracrine activities are improved by environmental hypoxia (Table 7). So the potential endorsement of hypoxic culture conditions for hMSC product generation would depend on the relative importance placed on the secretion of trophic factors compared to the capacity to differentiate into various lineages by the scientific community $[78,79]$.

The switch to chemical hypoxia leaves a slightly more complex landscape than environmental hypoxia in terms of the "hMSC checklist". Tables 8 summarise studies (from 2006 to date) which investigate the effects of chemical hypoxia, mediated via $\mathrm{CoCl}_{2}$ and DFO on hMSCs. It is apparent that both $\mathrm{CoCl}_{2}$ and $\mathrm{DFO}$ at various concentrations and 
incubation times upregulate HIF-1 $\alpha$ and increase the release of angiogenic mediators. However more conflicting data exists related to cell morphology, viability and proliferation rate. This increased variation could be explained by the different mode of hypoxic induction (chemical v environmental), variation in hypoxic mimetic concentration, incubation time and/or cell source. In this respect, environmental hypoxia appears superior as the data regarding hMSC characteristics is slightly less variable and mainly positive (the mixed pattern of data is further reinforced when including other species such as mice and rats, yet this species extension is beyond the scope of this review).

\section{The biology of acute and chronic hypoxia}

As cited above $\mathrm{O}_{2}$ sensing plays a role in genetic stability, survival, differentiation and proliferation of cells. The mechanism behind this powerful control is the tight regulation of gene expression. $\mathrm{O}_{2}$ enters the cells by diffusion. Once in the cytoplasm its level regulates the function of a transcription factor called Hypoxia Inducible Factor 1 (HIF1) which is a dimer composed of two subunits HIF $\alpha$ and HIF $\beta$ [82-84]. It is important to note that the production of the two subunits is $\mathrm{O}_{2}$-independent. This means that they are produced in the cells regardless of the level of $\mathrm{O}_{2}$. It is the dimerization of the two subunits that is $\mathrm{O}_{2}$-dependent. In a normoxic culture condition where hMSCs are exposed to a high percentage of $\mathrm{O}_{2}$, the enzymes HIF-Prolyl-Hydroxylases (HPHs), whose function relies on $\mathrm{O}_{2}$, hydroxylate the proline residues 402 and 564 on the alpha subunit of HIF1[85,171]. As a result, HIF1 $\alpha$ becomes tagged for ubiquitination and subsequently degraded. So, in a high level of cellular

$\mathrm{O}_{2} \mathrm{HIF} 1$ is not functional. In a setting where hMSCs are exposed to a physiological $\mathrm{O}_{2}$ level, HPHs become unable to perform the hydroxylation process allowing for the HIF $1 \alpha$ subunit to accumulate in the cytoplasm. This enables the HIF1 subunits to dimerize and translocate to the nucleus where they bind to specific DNA regions of gene promoters called Hypoxia Response Elements (HRE) [85,171]. This binding results in the regulation of hundreds of 
genes involved in various cellular functions such as angiogenesis, migration and metabolism $[18,19]$. So, in a low level of cellular $\mathrm{O}_{2}$ HIF1 is stabilised and functional and is considered a key regulator of cells’ response [85,172]

Hypoxic conditions can be maintained across both the short and long term (Refer Figure 4) often with differing end points in terms of cellular health. When hMSCs are cultured in hypoxia for a short-time, the cells become prone to apoptosis which is translated as a decrease in proliferation. Alternatively, an extended duration under hypoxic conditions gives the cells some time to adapt and reprogram so survival is promoted, and proliferation increases after a lag period $[22,100,123,173]$. One can argue here that the process is not an adaptation but a selection process since an MSC population is not homogeneous, or a combination of both adaptation and selection.

A closer look at HIF could offer an additional biological explanation to the MSC response to long-term exposure to hypoxia which appears biphasic. There are three types of HIF namely HIF1, HIF2 and HIF3 whose composition and production are similar. HIF1 is well studied and its role in controlling the cellular response to hypoxia is well established [111,142,174177]. The role of HIF2 in hMSC response to hypoxia is not as well assessed, however, it is more studied in several cancer types as well as in embryology [178]. HIF3 role in hypoxia is the least investigated with reports on its supportive [179] and/or inhibitory effects [180] on HIF1 [82]. Further to the variable role of HIF3 in response to oxygen when interacting with HIF1 differential expression of HIF3 has been documented in hMSCs related to epigenetic changes elicited by pro-inflammatory cytokines in an oxygen-independent manner [181]. In a review published by Mei Yee Koh and Garth Powis [171]) entitled "Passing the baton: the HIF switch", the authors discuss that between two of the types of HIF, HIF-1 and HIF-2, gene regulation is not completely overlapping with each HIF having unique genes that they regulate as well as some common ones. 
The modulation of gene expression in hMSCs via HIFs has been reported and is summarised in Table 9, and although the dissection to the level of individual HIFs in hMSCs has yet to emerge, in some cell lines HIF-1 drives the initial response to hypoxia while HIF-2 drives the chronic response to hypoxia [171] see Figure 5 [182]. One can suggest here that a switch from HIF1 to HIF2 or HIF3 occurs during hMSC response to chronic hypoxia. The mode of action of these two types of the transcription factor HIF could then be correlated to the twophase events that occur in MSC long-term hypoxia. That is the lag phase at the beginning of the exposure could be mainly driven by the expression of HIF1 which stimulates metabolic switching to enhance glycolysis [11,26,141]. As the switch from HIF type 1 to type 2 occurs, MSC multi-potency and cell cycle progression are promoted in hypoxia, with examples of this HIF switching seen in other stem cell types [178,183,184]. The correlation suggested here is a novel suggestion, and the pathways potentially involved in this time course are complex [102], which means like many other facets of MSC biology it requires further research and investigation but hopefully could become a final addition on the "hMSC checklist”.

\section{Conclusion and Future Perspectives}

This review shows that culturing hMSCs in low oxygen is beneficial for most of their characteristics in terms of the "hMSC checklist" (proposed) and should be used in therapy development. Understanding the biology of hMSC hypoxia in more detail along with improved experimental design and reporting would offer a better basis for successful translation into the clinic and enable the stem cell community to provide the "scientific evidence” that the FDA [6] and other regulators require. The consensus through open discussion we may be able to afford our "hMSC checklist" experimental assays may also help with the ongoing quest "to mean what we say" as scientists as well as gaining regulatory acceptance. Attributed to Dostoevsky "Intelligence alone is not nearly enough when it comes 
to acting wisely.” So maybe we need to be organised as well as intelligent to get MSCs to the point of regulatory compliant therapies of choice for both public and health care providers.

\section{References}

1. Mason C and P Dunnill (2008). A brief definition of regenerative medicine. Regen Med 3: $1-5$.

2. Parker GC, M Anastassova-Kristeva, HE Broxmeyer, WH Dodge, LM Eisenberg, UM Gehling, LM Guenin, R Huss, NI Moldovan, M Rao, EF Srour and MC Yoder (2004). Stem cells: shibboleths of development. Stem Cells Dev 13: 579-584.

3. Parker GC, M Anastassova-Kristeva, LM Eisenberg, M Rao, MA Williams, PR Sanberg and D English (2005). Stem Cells: Shibboleths of Development II. Stem Cells Dev 14: 463469.

4. Marks PW, CM Witten and RM Califf (2017). Clarifying Stem-Cell Therapy’s Benefits and Risks. New Engl J Medcine 376: 1007-1009.

5. Squillaro T, G Peluso and U Galderisi (2016). Review Clinical Trials With Mesenchymal Stem Cells : An Update. 25: 829-848.

6. Administration USF and D (2017). FDA Warns About Stem Cell Therapies. https://www.fda.gov/forconsumers/consumerupdates/ucm286155.htm [last accessed July 2018]

7. Marquez-Curtis LA, A Janowska-Wieczorek, LE McGann and JAW Elliott (2015). Mesenchymal stromal cells derived from various tissues: Biological, clinical and cryopreservation aspects. Cryobiology 71: 181-197.

8. Lotfinejad P, K Shamsasenjan, A Movassaghpour, J Majidi and B Baradaran (2014). 
Immunomodulatory Nature and Site Specific Mesenchymal Stem Cells : a Hope in Cell Therapy Affinity of. Adv Pharm Bull 4: 5-13.

9. Salem HK and C Thiemermann (2010). Mesenchymal stromal cells: Current understanding and clinical status. Stem Cells 28: 585-596.

10.https://clinicaltrials.gov/ct2/results?term=+mesenchymal+stem+cells\&Search=Search,.[La st accessed March 2018]

11. Estrada JC, C Albo, A Benguría, A Dopazo, P López-Romero, L Carrera-Quintanar, E Roche, EP Clemente, JA Enríquez, A Bernad and E Samper (2012). Culture of human mesenchymal stem cells at low oxygen tension improves growth and genetic stability by activating glycolysis. Cell Death Differ 19: 743-755.

12. Heathman TRJ, A Stolzing, C Fabian, QA Rafiq, K Coopman, AW Nienow, B Kara and CJ Hewitt (2015). Serum-free process development: Improving the yield and consistency of human mesenchymal stromal cell production. Cytotherapy 17: 1524-1535.

13. Agata H, N Watanabe, Y Ishii, N Kubo, S Ohshima, M Yamazaki, A Tojo and H Kagami (2009). Feasibility and efficacy of bone tissue engineering using human bone marrow stromal cells cultivated in serum-free conditions. Biochem Biophys Res Commun 382: 353-358.

14. Jung S, KM Panchalingam, L Rosenberg and LA Behie (2012). Ex vivo expansion of human mesenchymal stem cells in defined serum-free media. Stem Cells Int 2012: Article ID123030.

15. Mark P, M Kleinsorge, R Gaebel, C Lux and E Al. (2013). Human Mesenchymal Stem Cells Display Reduced Expression of CD105 after Culture in Serum-Free Medium. Stem Cells Int 2013: 1-8. 
16. Heathman TRJ, A Stolzing, C Fabian, QA Rafiq, K Coopman, AW Nienow, B Kara and CJ Hewitt (2016). Scalability and process transfer of mesenchymal stromal cell production from monolayer to microcarrier culture using human platelet lysate. Cytotherapy 18: 523535.

17. Bieback K, A Hecker, A Kocaömer, H Lannert, K Schallmoser, D Strunk and H Klüter (2009). Human alternatives to fetal bovine serum for the expansion of mesenchymal stromal cells from bone marrow. Stem Cells 27: 2331-2341.

18. Forsyth NR, A Kay, K Hampson, A Downing, R Talbot and J McWhir (2008). Transcriptome alterations due to physiological normoxic $\left(2 \% \mathrm{O}_{2}\right)$ culture of human embryonic stem cells. Regen Med 3: 817-833.

19. Kay AG, TP Dale, KM Akram, P Mohan, K Hampson, N Maffulli, MA Spiteri, AJ El Haj and NR Forsyth (2015). BMP2 repression and optimized culture conditions promote human bone marrow-derived mesenchymal stem cell isolation. Regen Med 10: 109-125.

20. Das R, H Jahr and E Farrell (2010). The Role of Hypoxia in Bone Marrow - Derived Mesenchymal Stem Cells : Considerations. Tissue Eng 16: 159-168.

21. Adesida AB, A Mulet-Sierra and NM Jomha (2012). Hypoxia mediated isolation and expansion enhances the chondrogenic capacity of bone marrow mesenchymal stromal cells. Stem Cell Res Ther 3: 9.

22. Basciano L, C Nemos, B Foliguet, $\mathrm{N}$ de Isla, M de Carvalho, $\mathrm{N}$ Tran and A Dalloul (2011). Long term culture of mesenchymal stem cells in hypoxia promotes a genetic program maintaining their undifferentiated and multipotent status. BMC Cell Biol 12: 12.

23. Holzwarth C, M Vaegler, F Gieseke, SM Pfister, R Handgretinger, G Kerst and I Muller (2010). Low physiologic oxygen tensions reduce proliferation and differentiation of human 
multipotent mesenchymal stromal cells. BMC Cell Biol 11: 11.

24. Jin Y, T Kato, M Furu, A Nasu, Y Kajita, H Mitsui, M Ueda, T Aoyama, T Nakayama, T Nakamura and J Toguchida (2010). Mesenchymal stem cells cultured under hypoxia escape from senescence via down-regulation of p16 and extracellular signal regulated kinase. Biochem Biophys Res Commun 391: 1471-1476.

25. Pattappa G, SD Thorpe, NC Jegard, HK Heywood, JD de Bruijn and DA Lee (2013). Continuous and uninterrupted oxygen tension influences the colony formation and oxidative metabolism of human mesenchymal stem cells. Tissue Eng Part C Methods 19: 68-79.

26. Dos Santos F, PZ Andrade, JS Boura, MM Abecasis, CL Da Silva and JMS Cabral (2010). Ex vivo expansion of human mesenchymal stem cells: A more effective cell proliferation kinetics and metabolism under hypoxia. J Cell Physiol 223: 27-35.

27. Maslova OO (2012). Current view of mesenchymal stem cells biology (Brief review). Biopolym Cell 28: 190-198.

28. Dominici M, K Le Blanc, I Mueller, I Slaper-Cortenbach, F Marini, D Krause, R Deans, A Keating, D Prockop and E Horwitz (2006). Minimal criteria for defining multipotent mesenchymal stromal cells. The International Society for Cellular Therapy position statement. Cytotherapy 8: 315-317.

29. Samsonraj RM, M Raghunath, V Nurcombe, JH Hui, AJ van Wijnen and SM Cool (2017). Concise Review: Multifaceted Characterization of Human Mesenchymal Stem Cells for Use in Regenerative Medicine. Stem Cells Transl Med 6: 2173-2185.

30. Samsonraj RM, B Rai, P Sathiyanathan, KJ Puan, O Rotzschke, JH Hui, M Raghunath, LW Stanton, V Nurcombe and SM Cool (2015). Establishing Criteria for Human Mesenchymal Stem Cell Potency. Stem Cells 33: 1878-1891. 
31. Rafiq QA, AW Nienow, CJ Hewitt and K Coopman (2017). The role of biopreservation in cell and gene therapy bioprocessing. Cell Gene Ther Insights 3: 335-344.

32. Binato R, T de Souza Fernandez, C Lazzarotto-Silva, B Du Rocher, A Mencalha, L Pizzatti, LF Bouzas and E Abdelhay (2013). Stability of human mesenchymal stem cells during in vitro culture: Considerations for cell therapy. Cell Prolif 46: 10-22.

33. Zaim M, S Karaman, G Cetin and S Isik (2012). Donor age and long-term culture affect differentiation and proliferation of human bone marrow mesenchymal stem cells. Ann Hematol 91: 1175-1186.

34. Stolzing A, E Jones, D McGonagle and A Scutt (2008). Age-related changes in human bone marrow-derived mesenchymal stem cells: consequences for cell therapies. Mech Ageing Dev 129: 163-173.

35. Wong TY (2015). Molecular mechanism of extrinsic factors affecting anti-aging of stem cells. World J Stem Cells 7: 512-520.

36. Oswald J, S Boxberger, B Jorgensen, S Feldmann, G Ehninger, M Bornhäuser and C Werner (2004). Mesenchymal Stem Cells Can Be Differentiated Into Endothelial Cells In Vitro. Stem Cells 22: 377-384.

37. Golpanian S, A Wolf, KE Hatzistergos and JM Hare (2016). Rebuilding the Damaged Heart: Mesenchymal Stem Cells, Cell-Based Therapy, and Engineered Heart Tissue. Physiol Rev 96: 1127-1168.

38. Gnecchi M, P Danieli and E Cervio (2012). Mesenchymal stem cell therapy for heart disease. Vascul Pharmacol 57: 48-55.

39. Madeira A, CL da Silva, F dos Santos, E Camafeita, JMS Cabral and I Sá-Correia (2012). 
Human mesenchymal stem cell expression program upon extended ex-vivo cultivation, as revealed by 2-de-based quantitative proteomics. PLoS ONE 7(8): e43523.

40. Ringden O, M Uzunel, I Rasmusson, M Remberger, B Sundberg, H L??nnies, H-U Marschall, A Dlugosz, A Szakos, Z Hassan, B Omazic, J Aschan, L Barkholt and K Le Blanc (2006). Mesenchymal Stem Cells for Treatment of Therapy-Resistant Graft-versus-Host Disease. Transplantation 81: 1390-1397.

41. Baldari S, G Di Rocco, M Piccoli, M Pozzobon, M Muraca and G Toietta (2017). Challenges and strategies for improving the regenerative effects of mesenchymal stromal cell-based therapies. Int J Mol Sci 18: 1-19.

42. Lee K, EH Joo, K Song, B Choi, S Kim, SJ Kim, M Kang, E Kyung, E Hye, K Song, B Choi, M Kim and S Kim (2016). Correction for Lee et al., Effects of lymphocyte profile on development of EBV-induced lymphoma subtypes in humanized mice. Proc Natl Acad Sci 113: E2470-E2470.

43. Kramer N, A Walzl, C Unger, M Rosner, G Krupitza and M Hengstschla (2013). In vitro cell migration and invasion assays. Mutat Res 752: 10-24.

44. Yu Y, Y Yin, RX Wu, XT He, XY Zhang and FM Chen (2017). Hypoxia and low-dose inflammatory stimulus synergistically enhance bone marrow mesenchymal stem cell migration. Cell Prolif 50: 1-10.

45. Akram KM, S Samad, MA Spiteri and NR Forsyth (2013). Mesenchymal stem cells promote alveolar epithelial cell wound repair in vitro through distinct migratory and paracrine mechanisms. Respir Res 14: 1-16.

46. Zepeda-Moreno A, I Taubert, I Hellwig, V Hoang, L Pietsch, VK Lakshmanan, W Wagner and AD Ho (2011). Innovative method for quantification of cell-cell adhesion in 96- 
well plates. Cell Adhes Migr 5: 215-219.

47. Busletta C, E Novo, L Valfrè Di Bonzo, D Povero, C Paternostro, M Ievolella, K Mareschi, I Ferrero, S Cannito, A Compagnone, A Bandino, S Colombatto, F Fagioli and M Parola (2011). Dissection of the biphasic nature of hypoxia-induced motogenic action in bone marrow-derived human mesenchymal stem cells. Stem Cells 29: 952-963.

48. Morris TJ, A Picken, DMC Sharp, NKH Slater, CJ Hewitt and K Coopman (2016). The effect of Me2SO overexposure during cryopreservation on HOS TE85 and hMSC viability, growth and quality. Cryobiology 73: 367-375.

49. Neri S, P Bourin, JA Peyrafitte, L Cattini, A Facchini and E Mariani (2013). Human Adipose Stromal Cells (ASC) for the Regeneration of Injured Cartilage Display Genetic Stability after In Vitro Culture Expansion. PLoS ONE 8(10): e77895.

50. Stultz BG, K McGinnis, EE Thompson, JL Lo Surdo, SR Bauer and DA Hursh (2016). Chromosomal Stability of Mesenchymal Stromal Cells During In Vitro Culture. Cytotherapy 18: 336-343.

51. Izadpanah R, C Trygg, B Patel, C Kriedt, J Dufour, JM Gimble and BA Bunnell (2006). Biologic properties of mesenchymal stem cells derived from bone marrow and adipose tissue. J Cell Biochem 99: 1285-1297.

52. Wagner W, AD Ho and M Zenke (2010). Different facets of aging in human mesenchymal stem cells. Tissue Eng Part B Rev 16: 445-453.

53. Choi MR, HY Kim, J-Y Park, TY Lee, CS Baik, YG Chai, KH Jung, KS Park, W Roh, KS Kim and SH Kim (2010). Selection of optimal passage of bone marrow-derived mesenchymal stem cells for stem cell therapy in patients with amyotrophic lateral sclerosis. Neurosci Lett 472: 94-98. 
54. Zhang Z-X, L-X Guan, K Zhang, S Wang, P-C Cao, Y-H Wang, Z Wang and L-J Dai (2007). Cytogenetic analysis of human bone marrow-derived mesenchymal stem cells passaged in vitro. Cell Biol Int 31: 645-648.

55. Izadpanah R, D Kaushal, C Kriedt, F Tsien, B Patel and BA Bunnell (2008). Long-term In vitro Expansion Alters the Biology of Adult Mesenchymal Stem Cells. Cancer Res 68: 4229-4238.

56. Bernardo ME, N Zaffaroni, F Novara, AM Cometa, MA Avanzini, A Moretta, D Montagna, R Maccario, R Villa, MG Daidone, O Zuffardi and F Locatelli (2007). Human bone marrow derived mesenchymal stem cells do not undergo transformation after long-term in vitro culture and do not exhibit telomere maintenance mechanisms. Cancer Res 67: 91429149.

57. Wang J, L Liao, S Wang and J Tan (2013). Cell therapy with autologous mesenchymal stem cells-how the disease process impacts clinical considerations. Cytotherapy 15: 893-904.

58. Park HW, J-S Shin and C-W Kim (2007). Proteome of mesenchymal stem cells. Proteomics 7: 2881-2894.

59. Timmers L, SK Lim, F Arslan, JS Armstrong, IE Hoefer, PA Doevendans, JJ Piek, RM El Oakley, A Choo, CN Lee, G Pasterkamp and DP V de Kleijn (2008). Reduction of myocardial infarct size by human mesenchymal stem cell conditioned medium. Stem Cell Res 1: 129-137.

60. Arslan F, RC Lai, MB Smeets, L Akeroyd, A Choo, ENE Aguor, L Timmers, H V. van Rijen, PA Doevendans, G Pasterkamp, SK Lim and DP de Kleijn (2013). Mesenchymal stem cell-derived exosomes increase ATP levels, decrease oxidative stress and activate PI3K/Akt pathway to enhance myocardial viability and prevent adverse remodeling after myocardial 
ischemia/reperfusion injury. Stem Cell Res 10: 301-312.

61. Chen TS, RC Lai, MM Lee, ABH Choo, CN Lee and SK Lim (2009). Mesenchymal stem cell secretes microparticles enriched in pre-microRNAs. Nucleic Acids Res 38: 215-224.

62. Ratajczak MZ, M Kucia, T Jadczyk, NJ Greco, W Wojakowski, M Tendera and J Ratajczak (2012). Pivotal role of paracrine effects in stem cell therapies in regenerative medicine: can we translate stem cell-secreted paracrine factors and microvesicles into better therapeutic strategies? Leukemia 26: 1166-1173.

63. Kusuma GD, J Carthew, R Lim and JE Frith (2017). Effect of the Microenvironment on Mesenchymal Stem Cell Paracrine Signaling: Opportunities to Engineer the Therapeutic Effect. Stem Cells Dev 26: 617-631.

64. Lopatina T, A Mazzeo, S Bruno, C Tetta, N Kalinina, R Romagnoli, M Salizzoni, M Porta and G Camussi (2014). The Angiogenic Potential of Adipose Mesenchymal Stem Cellderived Extracellular Vesicles is modulated by Basic Fibroblast Growth Factor. J Stem Cell Res Ther 4: 1-7.

65. Bernardo ME and WE Fibbe (2015). Mesenchymal stem cells and hematopoietic stem cell transplantation. Ann N Y Acad Sci 168: 215-221.

66. Gao F, SM Chiu, DAL Motan, Z Zhang, L Chen, H-L Ji, H-F Tse, Q-L Fu and Q Lian (2016). Mesenchymal stem cells and immunomodulation: current status and future prospects. Cell Death Dis 7: Article IDe2062.

67. Wuchter P, K Bieback, H Schrezenmeier, M Bornhäuser, LP Müller, H Bönig, W Wagner, R Meisel, P Pavel, T Tonn, P Lang, I Müller, M Renner, G Malcherek, R Saffrich, EC Buss, P Horn, M Rojewski, A Schmitt, AD Ho, R Sanzenbacher and M Schmitt (2015). Standardization of Good Manufacturing Practice-compliant production of bone marrow- 
derived human mesenchymal stromal cells for immunotherapeutic applications. Cytotherapy 17: 128-139.

68. Yi T and SU Song (2012). Immunomodulatory properties of mesenchymal stem cells and their therapeutic applications. Arch Pharm Res 35: 213-221.

69. Liang J, H Zhang, B Hua, H Wang, L Lu, S Shi, Y Hou, X Zeng, GS Gilkeson and L Sun (2010). Allogenic mesenchymal stem cells transplantation in refractory systemic lupus erythematosus: a pilot clinical study. Ann Rheum Dis 69: 1423-1429.

70. Keyszer G, M Christopeit, S Fick, M Schendel, BM Taute, G Behre, LP Müller and HJ Schmoll (2011). Treatment of severe progressive systemic sclerosis with transplantation of mesenchymal stromal cells from allogeneic related donors: Report of five cases. Arthritis Rheum 63: 2540-2542.

71. Linero I and O Chaparro (2014). Paracrine effect of mesenchymal stem cells derived from human adipose tissue in bone regeneration. PLoS ONE 9(9): e107001.

72. Torrente D, MF Avila, R Cabezas, L Morales, J Gonzalez, I Samudio and GE Barreto (2014). Paracrine factors of human mesenchymal stem cells increase wound closure and reduce reactive oxygen species production in a traumatic brain injury in vitro model. Hum Exp Toxicol 33: 673-684.

73. Baraniak, Priya R., McDevitt TC (2010). Paracrine Actions in Stem Cells and Tissue Regeneration. Regen Med 5: 121-143.

74. Page P, J Dejong, A Bandstra and R a Boomsma (2014). Effect of Serum and Oxygen Concentration on Gene Expression and Secretion of Paracrine Factors by Mesenchymal Stem Cells. Int J Cell Biol 2014: Article ID601063. 
75. Bain O, G Detela, H-W Kim, C Mason, A Mathur and IB Wall (2014). Altered hMSC functional characteristics in short-term culture and when placed in low oxygen environments: implications for cell retention at physiologic sites. Regen Med 9: 153-165.

76. Kasper G, N Dankert, J Tuischer, M Hoeft, T Gaber, JD Glaeser, D Zander, M Tschirschmann, M Thompson, G Matziolis and GN Duda (2007). Mesenchymal Stem Cells Regulate Angiogenesis According to Their Mechanical Environment. Stem Cells 25: 903910.

77. Wu Y, L Chen, PG Scott and EE Tredget (2007). Mesenchymal Stem Cells Enhance Wound Healing Through Differentiation and Angiogenesis. Stem Cells 25: 2648-2659.

78. Krampera M, J Galipeau, Y Shi, K Tarte, L Sensebe and LS Immunologi- (2014). Immunological characterization of multipotent mesenchymal stromal cells - The International Society for Cellular Therapy ( ISCT ) working proposal . Cytotherapy 10541061.

79. Galipeau J, M Krampera, J Barrett, F Dazzi, R Deans, J Debruijn, M Dominici, WE Fibbe, AP Gee, J Gimble, P Hematti, M Koh, K Leblanc, I Martin, I Mcniece, M Mendicino, S Oh, L Ortiz, D Phinney, V Planat, Y Shi, D Stroncek, S Viswanathan, D Weiss and L Sensebe (2016). International Society for Cellular Therapy prespective on immune functional assays for mesenchymal stromal cells as potency release criterion for adavanced phase clinical trials. Cytotherapy 18: 151-159.

80. Coopman K and N Medcalf (2014). From production to patient : challenges and approaches for delivering cell therapies. In: The Stem Cell Research Community, StemBook. Harvard Stem Cell Institute; Cambridge (MA). pp1-11

81. Ivanovic Z (2009). Hypoxia or in situ normoxia: The stem cell paradigm. J Cell Physiol 
219: $271-275$.

82. Duan C (2016). Hypoxia-inducible factor 3 biology: complexities and emerging themes. Am J Physiol - Cell Physiol 310: C260-C269.

83. Semenza GL and GL Wang (1992). A nuclear factor induced by hypoxia via de novo protein synthesis binds to the human erythropoietin gene enhancer at a site required for transcriptional activation. Mol Cell Biol 12: 5447-5454.

84. Prabhakar NR and GL Semenza (2012). Responses To Continuous and Intermittent Hypoxia Mediated By Hypoxia-Inducible Factors 1 and 2. Physiol Rev 92: 967-1003.

85. Haque N, MT Rahman, NH Abu Kasim and AM Alabsi (2013). Hypoxic culture conditions as a solution for mesenchymal stem cell based regenerative therapy. Sci World J 2013: Article ID632972.

86. http://medical-dictionary.thefreedictionary.com/normoxia. [Last accessed April 2018] 87. http://medical-dictionary.thefreedictionary.com/hypoxia. [Last accessed April 2018] 88. Rafiq QA, K Coopman, AW Nienow and CJ Hewitt (2013). A quantitative approach for understanding small-scale human mesenchymal stem cell culture - implications for large scale bioprocess deveopment. Biotechnol J 8: 459-471.

89. Peacock AJ (1998). Oxygen at high altitude. Br Med J 317: 1063-1066.

90. Vendruscolo, Francielo; Rossi, Marcio Jose; Schmidell, Willibaldo; Ninow JL (2012). Determination of oxygen solubility in liquid media. Int Sch Res Netw 2012: Article ID601458.

91. Verberk WCEP, DT Bilton, P Calosi and JI Spicer (2011). Oxygen supply in aquatic ectotherms: Partial pressure and solubility together explain biodiversity and size patterns. 
Ecology 92: 1565-1572.

92. Doran PM (2013). Bioprocess Engineering Principles, Second Edition. Academic Press, Cambridge, MA.

93. Gupta PA, X Ge, K Yordan and R Govind (214AD). A completely noninvasive method of dissolved oxygen monitoring in disposable small-scale cell culture vessels based on diffusion through permeable vessel walls. Biotechnol Prog 30: 172-177.

94. Vallejos JR, KA Brorson, AR Moreira and G Rao (2010). Dissolved oxygen and pH profile evolution after cryovial thaw and repeated cell passaging in a T-75 flask. Biotechnol Bioeng 105: 1040-1047.

95. von Köckritz-Blickwede M, N Zeitouni, J Fandrey and HY Naim (2015). Measuring oxygen levels in Caco-2 cultures. Hypoxia 3: 53-66.

96. Wu D and P Yotnda (2011). Induction and Testing of Hypoxia in Cell Culture. J Vis Exp $4-7$.

97. Liu L, Q Yu, J Lin, X Lai, W Cao, K Du, Y Wang, K Wu, Y Hu, L Zhang, H Xiao, Y Duan and H Huang (2011). Hypoxia-Inducible Factor-1 $\alpha$ Is Essential for Hypoxia-Induced Mesenchymal Stem Cell Mobilization into the Peripheral Blood. Stem Cells Dev 20: 19611971.

98. Kalinina N, D Kharlampieva, M Loguinova, I Butenko, O Pobeguts, A Efimenko, L Ageeva, G Sharonov, D Ischenko, D Alekseev, O Grigorieva, V Sysoeva, K Rubina, V Lazarev and V Govorun (2015). Characterization of secretomes provides evidence for adipose-derived mesenchymal stromal cells subtypes. Stem Cell Res Ther 6: 1-12.

99. Schive SW, MR Mirlashari, G Hasvold, M Wang, D Josefsen, HP Gullestad, O Korsgren, 
A Foss, G Kvalheim and H Scholz (2017). Human Adipose-Derived Mesenchymal Stem Cells Respond to Short-Term Hypoxia by Secreting Factors Beneficial for Human Islets In Vitro and Potentiate Antidiabetic Effect In Vivo. Cell Med 9: 103-116.

100. Valorani MG, E Montelatici, A Germani, A Biddle, D D’Alessandro, R Strollo, MP Patrizi, L Lazzari, E Nye, WR Otto, P Pozzilli and MR Alison (2012). Pre-culturing human adipose tissue mesenchymal stem cells under hypoxia increases their adipogenic and osteogenic differentiation potentials. Cell Prolif 45: 225-238.

101. Choi JR, B Pingguan-Murphy, WABW Abas, KW Yong, CT Poon, AN Azmi, SZ Omar, KH Chua, F Xu and WKZW Safwani (2015). In situ normoxia enhances survival and proliferation rate of human adipose tissue-derived stromal cells without increasing the risk of tumourigenesis. PLoS ONE 10(1): e0115034.

102. Moriyama H, M Moriyama, H Isshi, S Ishihara, H Okura, A Ichinose, T Ozawa, A Matsuyama and T Hayakawa (2014). Role of Notch Signaling in the Maintenance of Human Mesenchymal Stem Cells Under Hypoxic Conditions. Stem Cells Dev 23: 2211-2224.

103. Pachón-Peña G, C Serena, M Ejarque, J Petriz, X Duran, W Oliva-Olivera, R Si O, FJ Tinahones, S Fer Andez-Veledo and J Vendrell (2016). Tissue-Specific Progenitor and Stem Cells Obesity Determines the Immunophenotypic Profile and Functional Characteristics of Human Mesenchymal Stem Cells From Adipose Tissue. Stem Cells 5: 464-475.

104. Fábián Z, S Ramadurai, G Shaw, HP Nasheuer, W Kolch, C Taylor and F Barry (2014). Basic fibroblast growth factor modifies the hypoxic response of human bone marrow stromal cells by ERK-mediated enhancement of HIF-1 $\alpha$ activity. Stem Cell Res 12: 646-658.

105. Wagegg M, T Gaber, FL Lohanatha, M Hahne, C Strehl, M Fangradt, CL Tran, K Schönbeck, P Hoff, A Ode, C Perka, GN Duda and F Buttgereit (2012). Hypoxia Promotes 
Osteogenesis but Suppresses Adipogenesis of Human Mesenchymal Stromal Cells in a Hypoxia-Inducible Factor-1 Dependent Manner. PLoS ONE 7(9): e46483.

106. Cigognini D, D Gaspar, P Kumar, A Satyam, S Alagesan, C Sanz-Nogués, M Griffin, T O’Brien, A Pandit and DI Zeugolis (2016). Macromolecular crowding meets oxygen tension in human mesenchymal stem cell culture - A step closer to physiologically relevant in vitro organogenesis. Sci Rep 6: 1-11.

107. Saller MM, WC Prall, D Docheva, V Schoenitzer, T Popov, D Anz, H ClausenSchaumann, W Mutschler, E Volkmer, M Schieker and H Polzer (2012). Increased stemness and migration of human mesenchymal stem cells in hypoxia is associated with altered integrin expression. Biochem Biophys Res Commun 423: 379-385.

108. Carrancio S, N López-Holgado, FM Sánchez-Guijo, E Villarón, V Barbado, S Tabera, M Díez-Campelo, J Blanco, JF San Miguel and MC del Cañizo (2008). Optimization of mesenchymal stem cell expansion procedures by cell separation and culture conditions modification. Exp Hematol 36: 1014-1021.

109. Palumbo S, T-L Tsai and W-J Li (2014). Macrophage migration inhibitory factor regulates AKT signaling in hypoxic culture to modulate senescence of human mesenchymal stem cells. Stem Cells Dev 23: 852-865.

110. Nekanti U, S Dastidar, P Venugopal, S Totey and M Ta (2010). Increased Proliferation and Analysis of Differential Gene Expression in Human Wharton ’ s Jelly-derived Mesenchymal Stromal Cells under Hypoxia. Int J Biol Sci 6: 499-512.

111. Drela K, A Sarnowska, P Siedlecka, I Szablowska-Gadomska, M Wielgos, M Jurga, B Lukomska and K Domanska-Janik (2014). Low oxygen atmosphere facilitates proliferation and maintains undifferentiated state of umbilical cord mesenchymal stem cells in an hypoxia 
inducible factor-dependent manner. Cytotherapy 16: 881-892.

112. Peng L, X Shu, C Lang and X Yu (2015). Effects of hypoxia on proliferation of human cord blood-derived mesenchymal stem cells. Cytotechnology 1615-1622.

113. Jiang C, J Sun, Y Dai, P Cao, L Zhang, S Peng, Y Zhou, G Li, J Tang and J Xiang (2015). HIF-1A and C/EBPs transcriptionally regulate adipogenic differentiation of bone marrow-derived MSCs in hypoxia. Stem Cell Res Ther 6: 1-14.

114. Fink T, L Abildtrup, K Fogd, BM Abdallah, M Kassem, P Ebbesen and V Zachar (2004). Induction of Adipocyte-Like Phenotype in Human Mesenchymal Stem Cells by Hypoxia. Stem Cells 22: 1346-1355.

115. Tamama K, H Kawasaki, SS Kerpedjieva, J Guan, RK Ganju and CK Sen (2011). Differential roles of hypoxia inducible factor subunits in multipotential stromal cells under hypoxic condition. J Cell Biochem 112: 804-817.

116. Park IH, KH Kim, HK Choi, JS Shim, SY Whang, SJ Hahn, OJ Kwon and IH Oh (2013). Constitutive stabilization of hypoxia-inducible factor alpha selectively promotes the self-renewal of mesenchymal progenitors and maintains mesenchymal stromal cells in an undifferentiated state. Exp Mol Med 45: e44-11.

117. Hung S-P, JH Ho, Y-R V. Shih, T Lo and OK Lee (2012). Hypoxia promotes proliferation and osteogenic differentiation potentials of human mesenchymal stem cells. $\mathrm{J}$ Orthop Res 30: 260-266.

118. Fehrer C, R Brunauer, G Laschober, H Unterluggauer, S Reitinger, F Kloss, C Gülly, R Gaßner and G Lepperdinger (2007). Reduced oxygen tension attenuates differentiation capacity of human mesenchymal stem cells and prolongs their lifespan. Aging Cell 6: 745757. 
119. Markway BD, G-K Tan, G Brooke, JE Hudson, JJ Cooper-White and MR Doran (2010). Enhanced Chondrogenic Differentiation of Human Bone Marrow-Derived Mesenchymal Stem Cells in Low Oxygen Environment Micropellet Cultures. Cell Transplant 19: 29-42. 120. Volkmer E, BC Kallukalam, J Maertz, S Otto, I Drosse, H Polzer, W Bocker, M Stengele, D Docheva, W Mutschler and M Schieker (2010). Hypoxic Preconditioning of Human Mesenchymal Stem Cells Overcomes Hypoxia-Induced Inhibition of Osteogenic Differentiation. Tissue Eng Part A 16: 153-164.

121. Yang DC, MH Yang, CC Tsai, TF Huang, YH Chen and SC Hung (2011). Hypoxia inhibits osteogenesis in human mesenchymal stem cells through direct regulation of RUNX2 by TWIST. PLoS ONE 6(9): e23965.

122. Liu L, J Gao, Y Yuan, Q Chang, Y Liao and F Lu (2013). Hypoxia preconditioned human adipose derived mesenchymal stem cells enhance angiogenic potential via secretion of increased VEGF and bFGF. Cell Biol Int 37: 551-560.

123. Fotia C, A Massa, F Boriani, N Baldini and D Granchi (2015). Hypoxia enhances proliferation and stemness of human adipose-derived mesenchymal stem cells. Cytotechnology 67: 1073-1084.

124. Rosová I, M Dao, B Capoccia, D Link and JA Nolta (2008). Hypoxic Preconditioning Results in Increased Motility and Improved Therapeutic Potential of Human Mesenchymal Stem Cells. Stem Cells 26: 2173-2182.

125. Vertelov G, L Kharazi, MG Muralidhar, G Sanati, T Tankovich and A Kharazi (2013). High targeted migration of human mesenchymal stem cells grown in hypoxia is associated with enhanced activation of RhoA. Stem Cell Res Ther 4: 5.

126. Ahmed NE-MB, M Murakami, S Kaneko and M Nakashima (2016). The effects of 
hypoxia on the stemness properties of human dental pulp stem cells (DPSCs). Sci Rep 6: 35476.

127. Grayson WL, F Zhao, B Bunnell and T Ma (2007). Hypoxia enhances proliferation and tissue formation of human mesenchymal stem cells. Biochem Biophys Res Commun 358: 948-953.

128. Lavrentieva A, I Majore, C Kasper and R Hass (2010). Effects of hypoxic culture conditions on umbilical cord-derived human mesenchymal stem cells. Cell Commun Signal 8: 18.

129. Kakudo N, N Morimoto, T Ogawa, S Taketani and K Kusumoto (2015). Hypoxia enhances proliferation of human adipose-derived stem cells via HIF-1 $\alpha$ activation. PLoS ONE 10(10): e0139890.

130. Tsai CC, YJ Chen, TL Yew, LL Chen, JY Wang, CH Chiu and SC Hung (2011). Hypoxia inhibits senescence and maintains mesenchymal stem cell properties through downregulation of E2A-p21 by HIF-TWIST. Blood 117: 459-469.

131. Wimpenny I, K Hampson, Y Yang, N Ashammakhi and NR Forsyth (2010). One-step recovery of marrow stromal cells on nanofibers. Tissue Eng Part C Methods 16: 503-509. 132. Oliveira PH, JS Boura, MM Abecasis, JM Gimble, CL da Silva and JMS Cabral (2012). Impact of hypoxia and long-term cultivation on the genomic stability and mitochondrial performance of ex vivo expanded human stem/stromal cells. Stem Cell Res 9: 225-236. 133. Ueyama H, T Horibe, S Hinotsu, T Tanaka, T Inoue, H Urushihara, A Kitagawa and K Kawakami (2012). Chromosomal variability of human mesenchymal stem cells cultured under hypoxic conditions. J Cell Mol Med 16: 72-82. 
134. Crisostomo PR, Y Wang, TA Markel, M Wang, T Lahm and DR Meldrum (2008). Human mesenchymal stem cells stimulated by TNF- , LPS, or hypoxia produce growth factors by an NF B- but not JNK-dependent mechanism. AJP Cell Physiol 294: C675-C682. 135. Paquet J, M Deschepper, A Moya, D Logeart-Avramoglou, C Boisson-Vidal and H Petite (2015). Oxygen Tension Regulates Human Mesenchymal Stem Cell Paracrine Functions. Stem Cells Transl Med 4: 809-821.

136. Chang W, CY Lee, J-H Park, M-S Park, L-S Maeng, CS Yoon, MY Lee, K-C Hwang and Y-A Chung (2013). Survival of hypoxic human mesenchymal stem cells is enhanced by a positive feedback loop involving miR-210 and hypoxia-inducible factor 1. J Vet Sci 14: 6976.

137. Agrawal R, TP Dale, MA Al-Zubaidi, PB Malgulwar, NR Forsyth and R Kulshreshtha (2016). Pluripotent and multipotent stem cells display distinct hypoxic miRNA expression profiles. PLoS ONE 11(10): e0164976

138. Zhou Y, Y Zhu, L Zhang, T Wu, T Wu, W Zhang, AM Decker, J He, J Liu, Y Wu, X Jiang, Z Zhang, C Liang and D Zou (2016). Human Stem Cells Overexpressing MIR-21 Promote Angiogenesis in Critical Limb Ischemia by Targeting CHIP to Enhance HIF-1 $\alpha$ Activity. Stem Cells 34: 924-934.

139. Jing D, M Wobus, DM Poitz, M Bornhäuser, G Ehninger and R Ordemann (2012). Oxygen tension plays a critical role in the hematopoietic microenvironment in vitro. Haematologica 97: 331-339.

140. Yao Y, Q Deng, W Song, H Zhang, Y Li, Y Yang, X Fan, M Liu, J Shang, C Sun, Y Tang, X Jin, H Liu, B Huang and Y Zhou (2016). MIF Plays a Key Role in Regulating Tissue-Specific Chondro-Osteogenic Differentiation Fate of Human Cartilage Endplate Stem 
Cells under Hypoxia. Stem Cell Reports 7: 249-262.

141. Lord-Dufour S, IB Copland, LL Jr, M Post, C Khosla, J Galipeau, E Rassart and B Annabi (2009). Evidence for transcriptional regulation of the glucose-6- phosphate transporter by HIF-1 $\alpha$ : Targeting G6PT with mumbaistatin analogs in hypoxic mesenchymal stromal cells. Stem Cells 27: 489-497.

142. Palomäki S, M Pietilä, S Laitinen, J Pesälä, R Sormunen, P Lehenkari and P Koivunen (2013). HIF-1 $\alpha$ is upregulated in human mesenchymal stem cells. Stem Cells 31: 1902-1909.

143. Kojima K, T McQueen, Y Chen, R Jacamo, M Konopleva, N Shinojima, E Shpall, X Huang and M Andreeff (2011). p53 activation of mesenchymal stromal cells partially abrogates microenvironment-mediated resistance to FLT3 inhibition in AML through HIF1 $\alpha$-mediated down-regulation of CXCL12. Blood 118: 4431-4439.

144. Proulx-Bonneau S, A Guezguez and B Annabi (2011). A concerted HIF-1 $\alpha /$ MT1-MMP signalling axis regulates the expression of the 3BP2 adaptor protein in hypoxic mesenchymal stromal cells. PLoS ONE 6(6): e21511.

145. Zhou N, N Hu, JY Liao, LB Lin, C Zhao, WK Si, Z Yang, SX Yi, TX Fan, W Bao, X Liang, X Wei, H Chen, C Chen, Q Chen, X Lin and W Huang (2015). HIF-1 $\alpha$ as a regulator of BMP2-induced chondrogenic differentiation, osteogenic differentiation, and endochondral ossification in stem cells. Cell Physiol Biochem 36: 44-60.

146. Zeng H-L, Q Zhong, Y-L Qin, Q-Q Bu, X-A Han, H-T Jia and H-W Liu (2011). Hypoxia-mimetic agents inhibit proliferation and alter the morphology of human umbilical cord-derived mesenchymal stem cells. BMC Cell Biol 12: 32.

147. Oses C, B Olivares, M Ezquer, C Acosta, P Bosch, M Donoso, P Léniz and F Ezquer (2017). Preconditioning of adipose tissue-derived mesenchymal stem cells with deferoxamine 
increases the production of pro-angiogenic, neuroprotective and anti-inflammatory factors: Potential application in the treatment of diabetic neuropathy. PLoS ONE 12(5): e0178011.

148. Ciavarella C, S Fittipaldi, S Pedrini, F Vasuri, E Gallitto, A Freyrie, A Stella, E Gostjeva and G Pasquinelli (2015). In vitro alteration of physiological parameters do not hamper the growth of human multipotent vascular wall-mesenchymal stem cells. Front Cell Dev Biol 3: 10.

149. Yuan Z, J Zhang, Y Huang, Y Zhang, W Liu, G Wang, Q Zhang, G Wang, Y Yang, H Li and G Chen (2017). NRF2 overexpression in mesenchymal stem cells induces stem-cell marker expression and enhances osteoblastic differentiation. Biochem Biophys Res Commun 491: 228-235.

150. Teti G, S Focaroli, V Salvatore, E Mazzotti, L Ingra, A Mazzotti and M Falconi (2018). The Hypoxia-Mimetic Agent Cobalt Chloride Differently Affects Human Mesenchymal Stem Cells in Their Chondrogenic Potential. Stem Cells Int 2018: Article ID3237253.

151. Hsu S-H, C-T Chen and Y-H Wei (2013). Inhibitory Effects of Hypoxia on Metabolic Switch and Osteogenic Differentiation of Human Mesenchymal Stem Cells. Stem Cells 31: $2779-2788$.

152. Heirani-Tabasi A, H Naderi-Meshkin, MM Matin, M Mirahmadi, M Shahriyari, N Ahmadiankia, N Sanjar Moussavi, HR Bidkhori, M Raeesolmohaddeseen and AR Bahrami (2018). Augmented migration of mesenchymal stem cells correlates with the subsidiary CXCR4 variant. Cell Adhes Migr 12: 118-126.

153. Bidkhori HR, N Ahmadiankia, MM Matin, A Heirani, M Farshchian, H Naderi, M Shahriyari, M Dastpak and AR Bahrami (2016). Chemically primed bone - marrow derived mesenchymal stem cells show enhanced expression of chemokine receptors contributed to 
their migration capability. Iran J Basic Med Sci 19: 14-19.

154. Chai YC, LF Mendes, N van Gastel, G Carmeliet and FP Luyten (2018). Fine-tuning pro-angiogenic effects of cobalt for simultaneous enhancement of vascular endothelial growth factor secretion and implant neovascularization. Acta Biomater 72: 447-460.

155. Hastings CL, HM Kelly, MJ Murphy, FP Barry, FJ O’Brien and GP Duffy (2012). Development of a thermoresponsive chitosan gel combined with human mesenchymal stem cells and desferrioxamine as a multimodal pro-angiogenic therapeutic for the treatment of critical limb ischaemia. J Control Release 161: 73-80.

156. Wahl EA, TL Schenck, HG Machens and ER Balmayor (2016). VEGF released by deferoxamine preconditioned mesenchymal stem cells seeded on collagen-GAG substrates enhances neovascularization. Sci Rep 6: 1-12.

157. Jeon ES, JH Shin, SJ Hwang, GJ Moon, OY Bang and HH Kim (2014). Cobalt chloride induces neuronal differentiation of human mesenchymal stem cells through upregulation of microRNA-124a. Biochem Biophys Res Commun 444: 581-587.

158. Annabi B, Y-T Lee, S Turcotte, E Naud, RR Desrosiers, M Champagne, N Eliopoulos, J Galipeau and R Beliveau (2003). Hypoxia Promotes Murine Bone-Marrow-Derived Stromal Cell Migration and Tube Formation. Stem Cells 21: 337-347.

159. Hung SC, RR Pochampally, SC Hsu, CC Sanchez, SC Chen, J Spees and DJ Prockop (2007). Short-term exposure of multipotent stromal cells to low oxygen increases their expression of CX3CR1 and CXCR4 and their engraftment in vivo. PLoS ONE 2(5): e416.

160. Vono R, E Jover Garcia, G Spinetti and P Madeddu (2017). Oxidative Stress in Mesenchymal Stem Cell Senescence: Regulation by Coding and Noncoding RNAs. Antioxid Redox Signal 2017. 1-16. 
161. Bentivegna A, M Miloso and G Riva (2013). DNA Methylation Changes during In Vitro Propagation of Human Mesenchymal Stem Cells: Implications for Their Genomic Stability? Stem Cells Int 2013: Article ID192425.

162. De Witte SFH, FS Peters, A Merino, SS Korevaar, JBJ Van Meurs, L O’Flynn, SJ Elliman, PN Newsome, K Boer, CC Baan and MJ Hoogduijn (2018). Epigenetic changes in umbilical cord mesenchymal stromal cells upon stimulation and culture expansion. Cytotherapy. In Press. https://doi.org/10.1016/j.jcyt.2018.05.005.

163. Mathieu J, Z Zhang, A Nelson, DA Lamba, TA Reh, C Ware and H Ruohola-Baker (2013). Hypoxia induces re-entry of committed cells into pluripotency. Stem Cells 31: 17371748.

164. Hamidouche Z, K Rother, J Przybilla, A Krinner, D Clay, L Hopp, C Fabian, A Stolzing, H Binder, P Charbord and J Galle (2017). Bistable Epigenetic States Explain AgeDependent Decline in Mesenchymal Stem Cell Heterogeneity. Stem Cells 35: 694-704.

165. Van Den Beucken T, E Koch, K Chu, R Rupaimoole, P Prickaerts, M Adriaens, JW Voncken, AL Harris, FM Buffa, S Haider, MHW Starmans, CQ Yao, M Ivan, C Ivan, C V. Pecot, PC Boutros, AK Sood, M Koritzinsky and BG Wouters (2014). Hypoxia promotes stem cell phenotypes and poor prognosis through epigenetic regulation of DICER. Nat Commun 5: 1-13.

166. Prickaerts P, ME Adriaens, T van den Beucken, E Koch, L Dubois, VEH Dahlmans, C Gits, CTA Evelo, M Chan-Seng-Yue, BG Wouters and JW Voncken (2016). Hypoxia increases genome-wide bivalent epigenetic marking by specific gain of H3K27me3. Epigenetics and Chromatin 9: 1-19.

167. Tsai C-C, T-L Yew, D-C Yang, W-H Huang and S-C Hung (2012). Benefits of hypoxic 
culture on bone marrow multipotent stromal cells. Am J Blood Res 2: 148-159.

168. Perez-Campo FM and JA Riancho (2015). Epigenetic mechanisms regulating mesenchymal stem cell differentiation. Curr Genomics 16: 368-383.

169. Zych J, M a Stimamiglio, a C Senegaglia, PRS Brofman, B Dallagiovanna, S Goldenberg and a Correa (2013). The epigenetic modifiers 5-aza-2’-deoxycytidine and trichostatin A influence adipocyte differentiation in human mesenchymal stem cells. Braz J Med Biol Res 46: 405-416.

170. Costa V, L Raimondi, A Conigliaro, F Salamanna, V Carina, A De Luca, D Bellavia, R Alessandro, M Fini and G Giavaresi (2017). Hypoxia-inducible factor 1A may regulate the commitment of mesenchymal stromal cells toward angio-osteogenesis by mirna-675-5P. Cytotherapy 19: 1412-1425.

171. Koh MY and G Powis (2012). Passing the baton: The HIF switch. Trends Biochem Sci 37: 364-372.

172. Buravkova LB, ER Andreeva, V Gogvadze and B Zhivotovsky (2014). Mesenchymal stem cells and hypoxia: Where are we? Mitochondrion 19: 105-112.

173. Otto S, D Docheva, D Ph, W Mutschler, M Schieker, E Volkmer, BC Kallukalam, J Maertz, S Otto, I Drosse, H Polzer, W Bocker, M Stengele, D Docheva, W Mutschler, M Schieker and D Ph (2010). Hypoxic preconditioning of human mesenchymal stem cells overcomes hypoxia-induced inhibition of osteogenic differentiation. Tissue Eng A 16: 153164.

174. Cerrada I, A Ruiz-Saurí, R Carrero, C Trigueros, A Dorronsoro, JM Sanchez-Puelles, A Diez-Juan, JA Montero and P Sepúlveda (2012). Hypoxia-Inducible Factor 1 Alpha Contributes to Cardiac Healing in Mesenchymal Stem Cells-Mediated Cardiac Repair. Stem 
Cells Dev 22: 501-511.

175. Razban V, AS Lotfi, M Soleimani, H Ahmadi, M Massumi, S Khajeh, M Ghaedi, S Arjmand, S Najavand and A Khoshdel (2012). HIF-1 $\alpha$ Overexpression Induces Angiogenesis in Mesenchymal Stem Cells. Biores Open Access 1: 174-183.

176. Kiani AA, A Kazemi, R Halabian, M Mohammadipour, A Jahanian-Najafabadi and MH Roudkenar (2013). HIF-1alpha confers resistance to induced stress in bone marrow-derived mesenchymal stem cells. Arch Med Res 44: 185-193.

177. Lampert FM, C Kutscher, GB Stark and G Finkenzeller (2016). Overexpression of Hif1alpha in Mesenchymal Stem Cells Affects Cell-Autonomous Angiogenic and Osteogenic Parameters. J Cell Biochem 117: 760-768.

178. Christensen DR, PC Calder and FD Houghton (2015). GLUT3 and PKM2 regulate OCT4 expression and support the hypoxic culture of human embryonic stem cells. Sci Rep 5: $1-14$.

179. Li QF, XR Wang, YW Yang and H Lin (2006). Hypoxia upregulates hypoxia inducible factor (HIF)-3alpha expression in lung epithelial cells: characterization and comparison with HIF-1alpha. Cell Res 16: 548-558.

180. Makino Y, A Kanopka, WJ Wilson, H Tanaka and L Poellinger (2002). Inhibitory PAS domain protein (IPAS) is a hypoxia-inducible splicing variant of the hypoxia-inducible factor-3 $\alpha$ locus. J Biol Chem 277: 32405-32408.

181. Cuomo F, A Coppola, C Botti, C Maione, A Forte, L Scisciola, G Liguori, I Caiafa, MV Ursini, U Galderisi, M Cipollaro, L Altucci and G Cobellis (2018). Pro-inflammatory cytokines activate hypoxia-inducible factor $3 \alpha$ via epigenetic changes in mesenchymal stromal/stem cells. Sci Rep 8: 1-12. 
182. Keith B, RS Johnson and MC Simon (2011). HIF1 $\alpha$ and HIF2 $\alpha$ : sibling rivalry in hypoxic tumour growth and progression. Nat Rev Cancer 12: 9-22.

183. Covello KL, J Kehler, H Yu, JD Gordan, AM Arsham, CJ Hu, PA Labosky, MC Simon and B Keith (2006). HIF-2 \{alpha\} regulates Oct-4: effects of hypoxia on stem cell function, embryonic development, and tumor growth. Genes Dev 20: 557-570.

184. Forristal CE, KL Wright, NA Hanley, ROC Oreffo and FD Houghton (2010). Hypoxia inducible factors regulate pluripotency and proliferation in human embryonic stem cells cultured at reduced oxygen tensions. Reproduction 139: 85-97.

Figure legends

Figure 1: Human MSC checklist. 'Critical to quality’ therapy-specific attributes that could be defined. The above list could serve as a checklist when deciding which assays to implement when conducting a study to produce regulatory compliant hMSCs. 


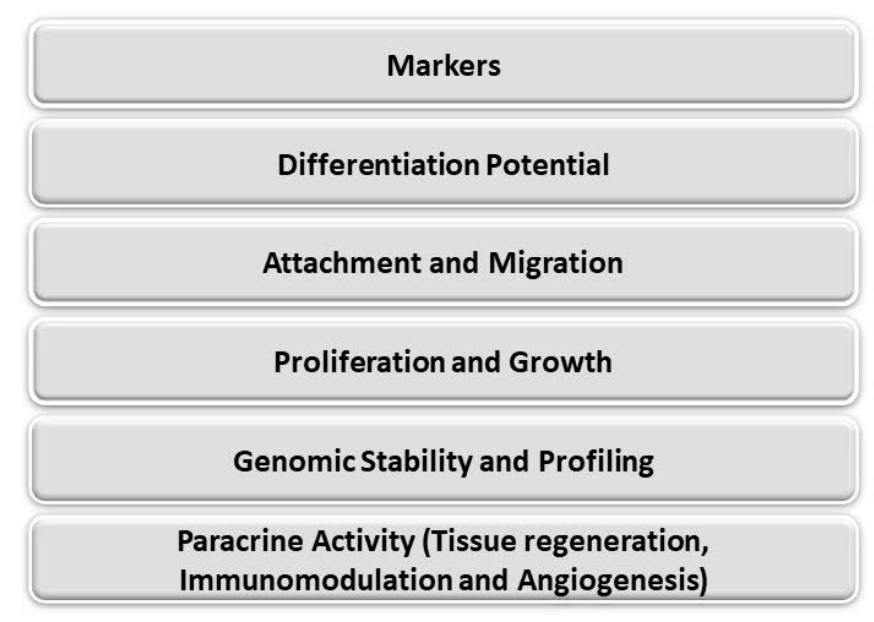

Figure 2: A schematic representation of the levels of gaseous (tissue culture head space) and dissolved (media dissolution of $\mathrm{O}_{2}$ ) oxygen in tissue culture illustrating that at $5 \% \mathrm{O}_{2}$, any increase in; Temperature (T) and/or Salinity (S or mg/L) and/or Pressure (p) will see gaseous $\mathrm{O}_{2}$ (culture headspace) will fall and dissolved $\mathrm{O}_{2}$ (media) will rise. ${ }^{1}$ Henry's law put into mathematical terms (at constant temperature) provides $\mathrm{p}=\mathrm{kHc}$ where $\mathrm{p}=$ the partial pressure of the solute in the gas above the solution; $\mathrm{c}=$ the concentration of the solute; $\mathrm{k}=$ the solubility of the substance; $\mathrm{H}$ = Henry's law constant (which depends on the solute, the solvent, and the temperature). ${ }^{2}$ Fick's Law essentially states that the rate of diffusion of a gas across a permeable membrane is determined by the membrane itself (material, thickness and surface area) the partial pressure gradient of the gas across the membrane: $\mathrm{V}^{\prime}$ gas $=$ $D^{*} A^{*} \Delta P / T$ where $V^{\prime}$ gas $=$ Rate of gas diffusion across permeable membrane; $D=$ Diffusion coefficient of that particular gas for that membrane; $\mathrm{A}=$ Surface Area of the membrane; $\Delta \mathrm{P}=$ Difference in partial pressure of the gas across the membrane; $\mathrm{T}=$ Thickness of the 
membrane.

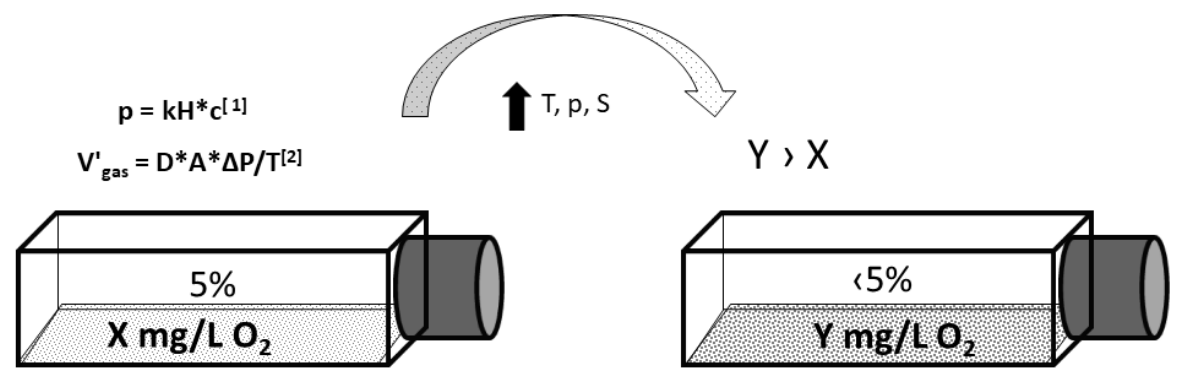

$[\mathrm{kH} \mathrm{O}: 769.2 \mathrm{~L} \cdot \mathrm{atm} / \mathrm{mol}]$

Figure 3: A generalised schematic representation summarising the effects of hypoxic cell culture conditions on human mesenchymal stem cells. Closed (black) arrows represent a positive influence of hypoxia, open (white) arrows represent no significant impact of hypoxic conditions and the patterned (grey) arrows reflect a mixed response displaying both positive and negative outputs. 


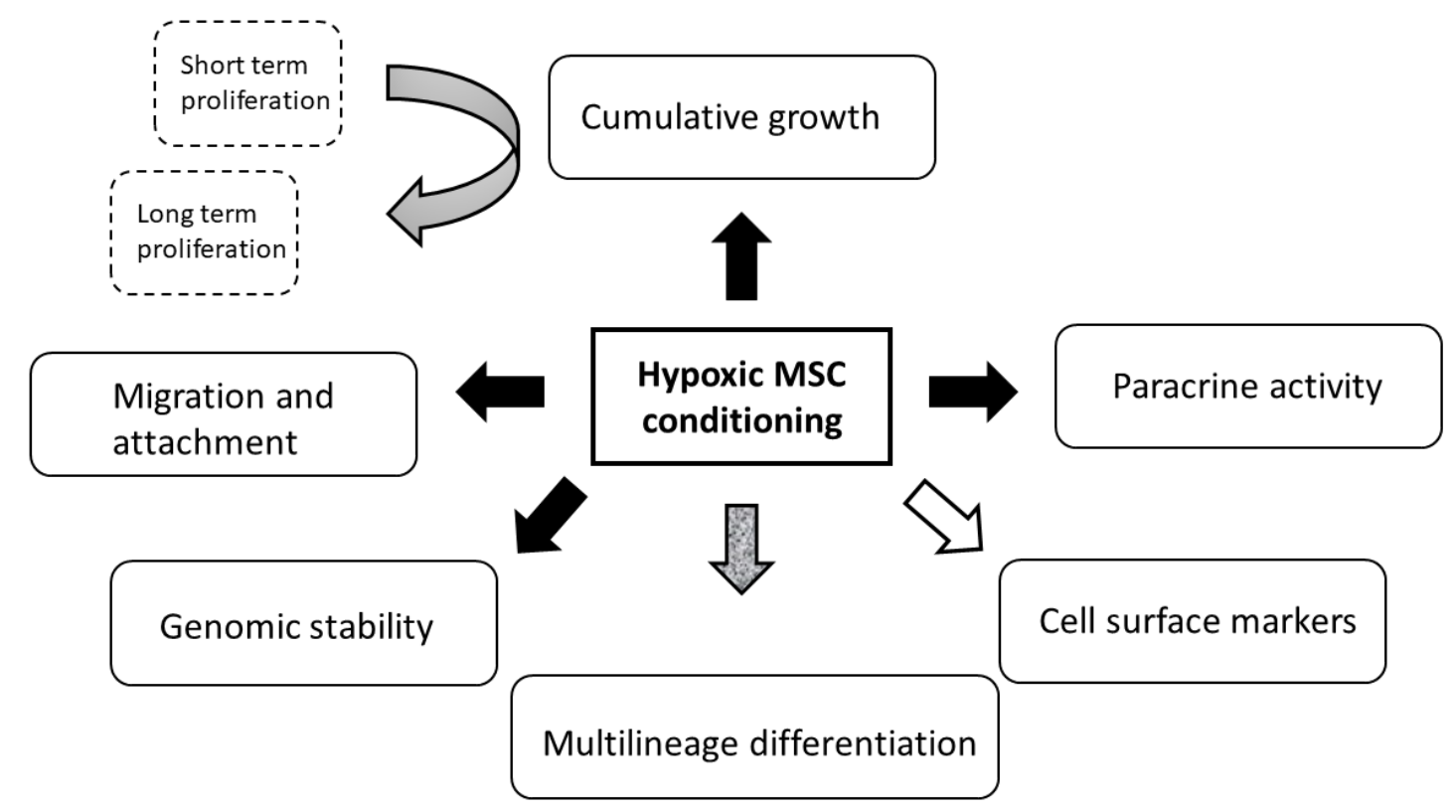

Figure 4: Summary of a review by Buravkova et al., [172] on the impact of chronic and acute hypoxia on hMSCs. Acute exposure (maximum duration of 72 hours to a level of atmospheric oxygen between 0 and 5\%) and chronic exposure (minimally, one week to continuously, with a level of atmospheric oxygen between 0.5 to 10\%). Analysis took into consideration MSC viability, proliferation, migration, metabolism, angiogenic activity and gene expression. 
Short-term hypoxia

Stress factor for MSCs

Decreased expression of anti-apoptotic proteins

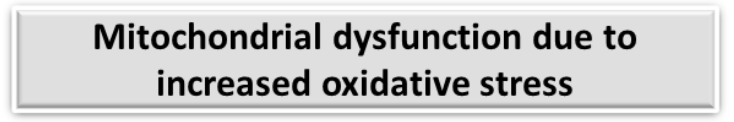

Increased expression of stress response proteins

\section{Provokes cell damage}

VS

Long-term hypoxia

Reflects the in-vivo niche more adequately

Maintained MSC undifferentiated state

Allows for HIF feedback

\section{Could be beneficial for therapy} development

No damaging effects on the cells

Figure 5: HIF1 and HIF2 mode of action. "HIF-1 drives the initial response to hypoxia while

HIF-2 drives the chronic response to hypoxia” [85].
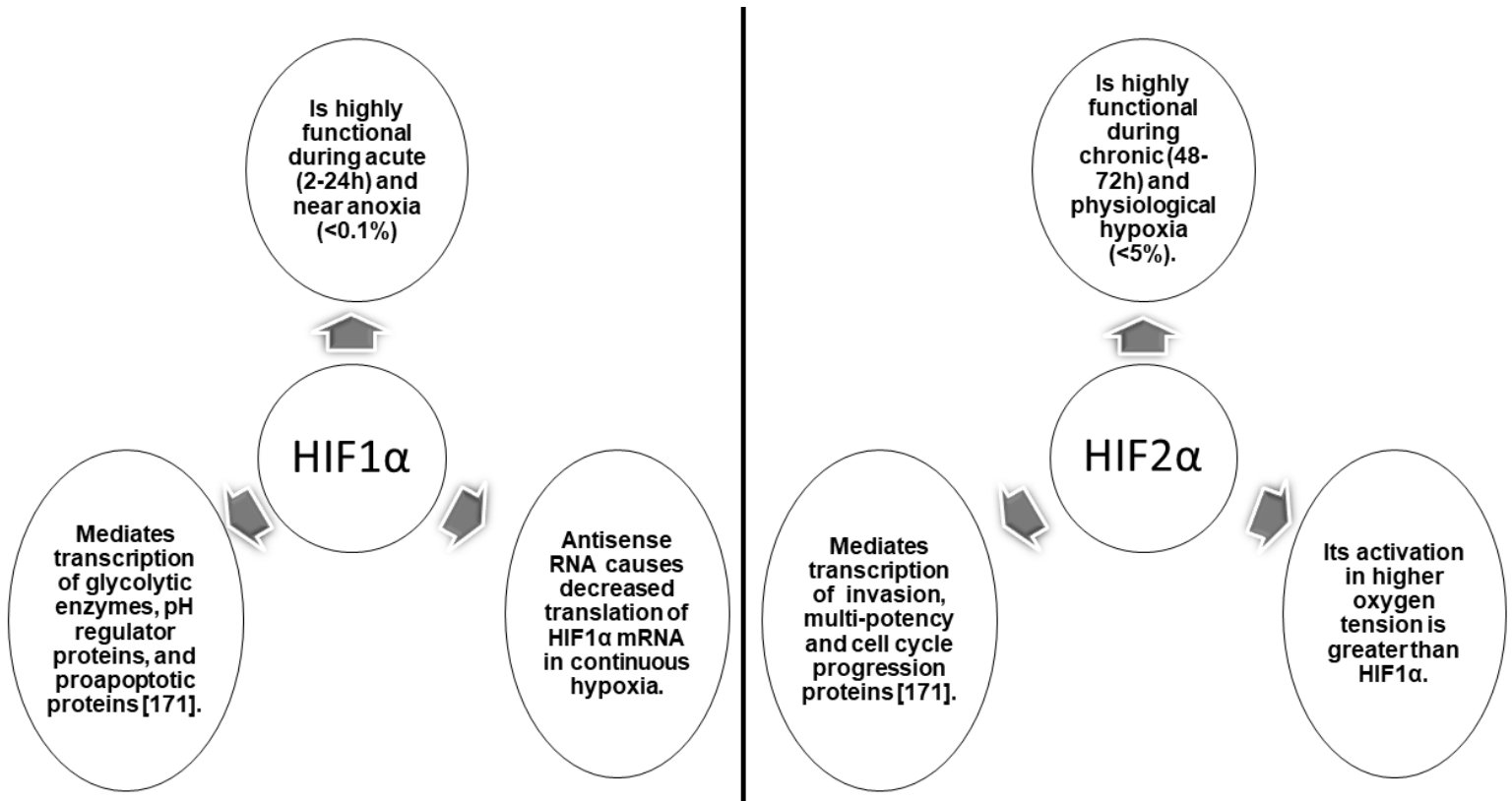
Table 1: Methods of induction of hypoxia with strengths and limitations

(*https://www.accessdata.fda.gov/drugsatfda_docs/nda/2004/076019_S000_DEFEROXAMI

NE\%20MESYLATE_PRNTLBL.pdf, accessed on 10/05/2018).

\begin{tabular}{|c|c|c|}
\hline Method & Strengths & Limitations \\
\hline \multirow{7}{*}{$\begin{array}{l}\text { Hypoxia induction using a } \\
\text { hypoxic sub-chamber [19] }\end{array}$} & Cheap & $\begin{array}{l}\text { Re-oxygenation periods during activities such } \\
\text { as media change (unless done in hypoxia }\end{array}$ \\
\hline & Easy to operate & $\begin{array}{l}\text { No oxygen monitoring (although some oxygen } \\
\text { controllers are available) }\end{array}$ \\
\hline & Efficient gas consumption & Size \\
\hline & \multirow[t]{4}{*}{ Transportable } & $\begin{array}{l}\text { Repeated re-flushing may be required to } \\
\text { maintain low oxygen levels }\end{array}$ \\
\hline & & Gas leak could be a problem \\
\hline & & $\begin{array}{l}\text { Size limitation and chamber to chamber } \\
\text { variability }\end{array}$ \\
\hline & & Minimum of two air exposure events per week \\
\hline \multirow{7}{*}{$\begin{array}{l}\text { Hypoxia induction using an } \\
\text { hypoxic incubator [19] }\end{array}$} & $\begin{array}{l}\text { Humidity, temperature, oxygen and } \mathrm{CO}_{2} \text { levels } \\
\text { of the incubator are monitored }\end{array}$ & $\begin{array}{l}\text { Re-oxygenation of the incubator with every } \\
\text { door opening }\end{array}$ \\
\hline & Easy to operate & $\begin{array}{l}\text { Re-oxygenation periods during activities such } \\
\text { as microscopic examination }\end{array}$ \\
\hline & $\begin{array}{l}\text { Easier to incorporate controls / replicates into } \\
\text { experimental plan }\end{array}$ & $\begin{array}{l}\text { No oxygen monitoring when cells are out of } \\
\text { the incubator. }\end{array}$ \\
\hline & \multirow[t]{4}{*}{ Reduced size constraints } & The range of oxygen levels can be limited \\
\hline & & Gas consumption \\
\hline & & $\begin{array}{l}\text { One air exposure event per week for single } \\
\text { user }\end{array}$ \\
\hline & & Air exposure events per week for multi-users \\
\hline \multirow{5}{*}{$\begin{array}{l}\text { Hypoxia induction using a } \\
\text { hypoxic Glovebox or } \\
\text { workstation [19] }\end{array}$} & No disruption to the hypoxic environment & Cost \\
\hline & $\begin{array}{l}\text { Robust oxygen, } \mathrm{CO}_{2} \text {, humidity and } \\
\text { temperature monitoring }\end{array}$ & Maintenance/servicing \\
\hline & Better reflection of the in-vivo niche & Cleaning \\
\hline & $\begin{array}{l}\text { Workstation can be large enough to host all } \\
\text { activities or equipment such as a microscope }\end{array}$ & $\begin{array}{l}\text { Access to the chamber without disruption of } \\
\text { the hypoxic environment }\end{array}$ \\
\hline & Air exposure events per week & Gas consumption \\
\hline \multirow{4}{*}{$\begin{array}{l}\text { Hypoxia induction using } \\
\text { cobalt chloride }\end{array}$} & Cheap & $\begin{array}{l}\text { Optimal dose and incubation time must be } \\
\text { assessed }\end{array}$ \\
\hline & Easy and accurate preparation & May cause cellular toxicity \\
\hline & No need for oxygen monitoring & $\begin{array}{l}\text { Intracellular accumulation with unknown } \\
\text { effects }\end{array}$ \\
\hline & Useful model to study hypoxia effects & Could be hazardous to user \\
\hline \multirow{7}{*}{$\begin{array}{l}\text { Hypoxia induction using } \\
\text { deferoxamine mesylate }\end{array}$} & FDA approved* & $\begin{array}{l}\text { Optimal dose and incubation time must be } \\
\text { assessed }\end{array}$ \\
\hline & Utilised in clinical setting & \multirow[t]{6}{*}{$\begin{array}{l}\text { May cause cytotoxic effects at longer } \\
\text { exposure periods }\end{array}$} \\
\hline & Cheap & \\
\hline & Easy and accurate preparation & \\
\hline & Not classified as hazardous & \\
\hline & No need for oxygen monitoring & \\
\hline & Useful model system & \\
\hline
\end{tabular}


Table 2: The consequence of hypoxia on hMSC cell surface phenotype. [Key to source of human Mesenchymal Stem Cells (hMSCs) column abbreviations: AD; Adipose tissue: BM; Bone Marrow: DP; Dental Pulp: WJ; Wharton’s Jelly: UC; Umbilical Cord: UCB; Umbilical Cord Blood: Other sources written in full).

\begin{tabular}{|c|c|c|c|}
\hline Effect of hypoxia & $\begin{array}{l}\text { Hypoxia conditions (\% } \\
\mathrm{O}_{2} \text { and duration) }\end{array}$ & $\begin{array}{l}\text { Source of } \\
\text { hMSC }\end{array}$ & Ref \\
\hline \multicolumn{4}{|c|}{ Cell surface markers } \\
\hline \multirow[t]{6}{*}{ ADMSC cell surface markers unaltered } & $1 \% ; 48 h$ & $A D$ & 97 \\
\hline & $1 \% ; 48 h$ & $A D$ & 98 \\
\hline & $1 \% ; 48 \mathrm{~h}$ & $A D$ & 99 \\
\hline & $2 \% ; 7$ days & $A D$ & 100 \\
\hline & $2 \%$; up to 21 days & $A D$ & 101 \\
\hline & $\begin{array}{l}\text { 5\%; Early \& late } \\
\text { passage }\end{array}$ & $A D$ & 102 \\
\hline ADMSC cell surface markers slightly altered & $5 \%$; up to 14 days & $A D$ & 103 \\
\hline \multirow[t]{7}{*}{ BMMSC cell surface markers unaltered } & $2 \& 0.2 \% ; 21$ days & BM & 19 \\
\hline & $1 \%$; up to $24 \mathrm{~h}$ & BM & 104 \\
\hline & $<2 \% ; 14$ days & BM & 105 \\
\hline & $2 \% ; 7-14$ days & BM & 106 \\
\hline & $2 \% ; 14$ days & BM & 26 \\
\hline & $2 \%$; up to 21 days & BM & 107 \\
\hline & $5 \%$; up to passage 4 & BM & 108 \\
\hline \multirow[t]{2}{*}{ BMMSC cell surface markers upregulated } & $1 \%$; up to 90 days & BM & 109 \\
\hline & $\begin{array}{l}2 \% \& 5 \% ; \text { up to } 21 \\
\text { days }\end{array}$ & BM & 25 \\
\hline WJMSC cell surface markers unaltered & $\begin{array}{l}2-3 \% \text {; up to passage } \\
10\end{array}$ & WJ & 110 \\
\hline
\end{tabular}




\begin{tabular}{|l|l|c|c|}
\hline & $5 \% ; 14$ days & WJ & 111 \\
\hline UCBMSC cell surface markers unaltered & $5 \% ; 5$ days & UCB & 112 \\
\hline
\end{tabular}

Table 3: The effect of hypoxia on hMSC multi-lineage differentiation. Hypoxia appears to assist in the maintenance of chondrogenic differentiation while it may improve or diminish osteogenic and adipogenic differentiation. [Key to source of human Mesenchymal Stem Cells (hMSCs) column abbreviations: AD; Adipose tissue: BM; Bone Marrow: DP; Dental Pulp: WJ; Wharton’s Jelly: UC; Umbilical Cord: UCB; Umbilical Cord Blood: Other sources written in full).

\begin{tabular}{|c|c|c|c|}
\hline Effect of hypoxia & $\begin{array}{l}\text { Hypoxia conditions }\left(\% \mathrm{O}_{2} \text { and }\right. \\
\text { duration) }\end{array}$ & $\begin{array}{c}\text { Source of } \\
\text { hMSC }\end{array}$ & Ref \\
\hline \multicolumn{4}{|c|}{ Differentiation potential } \\
\hline \multirow[t]{4}{*}{ Increased adipogenic differentiation } & $0.2 \% ; 7-14 d$ & BM & 113 \\
\hline & $1 \%$; up to $3 d$ & BM & 114 \\
\hline & $1 \%$; up to 90 days & BM & 109 \\
\hline & $1 \% ; 100 d$ & BM & 24 \\
\hline \multirow[t]{6}{*}{ Decreased adipogenic differentiation } & $1 \% ; 7$ days & BM & 115 \\
\hline & $1 \%$; 28 days & BM & 116 \\
\hline & $1 \% ; 28$ days & BM & 117 \\
\hline & $2 \% ; 7-14$ day & BM & 106 \\
\hline & $<2 \% ; 14$ days & BM & 105 \\
\hline & $3 \% ; 28-31$ days & BM & 118 \\
\hline $\begin{array}{l}\text { No significant effect on adipogenesis or } \\
\text { osteogenesis }\end{array}$ & $2 \% ; 24 h$ & BM & 44 \\
\hline $\begin{array}{l}\text { No significant effect on osteogenesis or } \\
\text { adipogenesis }\end{array}$ & $2 \% ; 14$ days & BM & 26 \\
\hline
\end{tabular}




\begin{tabular}{|c|c|c|c|}
\hline \multirow[t]{5}{*}{ Enhanced chondrogenic potential } & $1 \% ; 100$ days & BM & 24 \\
\hline & $2 \%$; 14 days & BM & 119 \\
\hline & $2 \%$; 42 days & BM & 19 \\
\hline & 2 \& 5\%; 21 days & BM & 25 \\
\hline & $3 \% ; 21$ days & BM & 21 \\
\hline No significant effect on chondrogenesis & $2 \% 7-14$ day & BM & 106 \\
\hline \multirow{4}{*}{$\begin{array}{l}\text { Enhanced osteogenic differentiation } \\
\text { potential }\end{array}$} & $1 \% ; 28$ days & BM & 117 \\
\hline & $1 \%$; up to 90 days & BM & 109 \\
\hline & $\begin{array}{l}2 \% ; 3 \text { day } \\
\text { (preconditioning)then } 21 \\
\text { days }\end{array}$ & BM & 120 \\
\hline & $<2 \% ; 14$ days & BM & 105 \\
\hline \multirow{7}{*}{$\begin{array}{l}\text { Impaired osteogenic differentiation } \\
\text { potential }\end{array}$} & $0.2 \% ; 7-14 d$ & BM & 113 \\
\hline & $1 \% ; 72 \mathrm{~h}$ & BM & 121 \\
\hline & $1 \% ; 7 d$ & BM & 115 \\
\hline & $1 \% ; 28 d$ & BM & 116 \\
\hline & $2 \% ; 21$ days & BM & 120 \\
\hline & $2 \% \& 5 \% ; 21$ days & BM & 25 \\
\hline & $3 \%$; 28-31 days & BM & 118 \\
\hline No significant effect on osteogenesis & $1 \% ; 100$ days & BM & 24 \\
\hline $\begin{array}{l}\text { No significant effect on osteogenesis or } \\
\text { chondrogenesis }\end{array}$ & 2\%; 7-14 day & BM & 106 \\
\hline \multirow[t]{4}{*}{ No effect on tri-lineage differentiation } & $1 \% ; 48 h$ & $A D$ & 122 \\
\hline & $1 \% ; 48 \mathrm{~h}$ & $A D$ & 99 \\
\hline & $1-3 \% ; 21$ days & $A D$ & 123 \\
\hline & $2-3 \%$; up to passage 10 & WJ & 110 \\
\hline Enhanced tri-lineage differentiation & $5 \% ; 21$ days & $A D$ & 102 \\
\hline
\end{tabular}


Table 4: The effect of hypoxia on hMSC attachment and migration. [Key to source of human Mesenchymal Stem Cells (hMSCs) column abbreviations: AD; Adipose tissue: BM; Bone Marrow: DP; Dental Pulp: WJ; Wharton’s Jelly: UC; Umbilical Cord: UCB; Umbilical Cord Blood: Other sources written in full).

\begin{tabular}{|c|c|c|c|}
\hline Effect of hypoxia & $\begin{array}{l}\text { Hypoxia conditions (\% } \\
\mathrm{O}_{2} \text { and duration) }\end{array}$ & $\begin{array}{c}\text { Source of } \\
\text { hMSC }\end{array}$ & Ref \\
\hline \multicolumn{4}{|c|}{ Attachment and migration } \\
\hline \multirow[t]{7}{*}{ Higher migration rate } & $1-3 \% ; 24 h$ & BM & 124 \\
\hline & 1\%; 7 days & BM & 117 \\
\hline & $2 \% ; 72 h$ & BM & 107 \\
\hline & $3 \% ; 6 \mathrm{~h}$ & BM & 47 \\
\hline & $5 \% ; 4 \mathrm{~h}$ & BM & 125 \\
\hline & $5 \%$; up to 14 days & $A D$ & 103 \\
\hline & $5 \% ; 24 h$ & $\mathrm{DP}$ & 126 \\
\hline $\begin{array}{l}\text { Increased expression of cell adhesion } \\
\text { molecules }\end{array}$ & $2 \% ; 72 h$ & BM & 107 \\
\hline $\begin{array}{l}\text { Increased motility and vascularisation and/or } \\
\text { innervation of tissue }\end{array}$ & $1-3 \% ; 24 h$ & BM & 124 \\
\hline
\end{tabular}

Table 5: The impact of hypoxia on hMSC proliferation and growth. [Key to source of human Mesenchymal Stem Cells (hMSCs) column abbreviations: AD; Adipose tissue: BM; Bone Marrow: DP; Dental Pulp: WJ; Wharton’s Jelly: UC; Umbilical Cord: UCB; Umbilical Cord Blood: Other sources written in full). 


\begin{tabular}{|c|c|c|c|}
\hline Effect of hypoxia & $\begin{array}{l}\text { Hypoxia conditions (\% } \\
\mathrm{O}_{2} \text { and duration) }\end{array}$ & $\begin{array}{l}\text { Source of } \\
\text { hMSC }\end{array}$ & Ref \\
\hline \multicolumn{4}{|c|}{ Growth and proliferation } \\
\hline \multirow[t]{3}{*}{ Enhanced MSC expansion } & $2 \% ; 7$ days & $\mathrm{BM}$ & 127 \\
\hline & $5 \%$; up to passage 4 & BM & 108 \\
\hline & $5 \%$; up to 100 days & $A D$ & 102 \\
\hline Enhanced MSC expansion and proliferation & $2 \%$; up to 12 days & BM & 26 \\
\hline \multirow[t]{14}{*}{ Increased proliferation rate } & 1-3\%; 72, 96 \& 144h & $A D$ & 123 \\
\hline & $1.5,2.5 \& 5 \% ; 72 h$ & UC & 128 \\
\hline & $1 \% ; 7$ days & BM & 117 \\
\hline & $1 \% ; 7$ days & $A D$ & 129 \\
\hline & $1 \% ; 2$ passage ( 8 days) & BM & 116 \\
\hline & $1 \%$; up to 84 days & BM & 130 \\
\hline & $2 \% ; 24 h$ & BM & 44 \\
\hline & 2\%; 3-7 day & BM & 127 \\
\hline & $2 \%$; up to 14 days & $A D$ & 100 \\
\hline & $2 \%$; up to 21 days & $A D$ & 101 \\
\hline & $\begin{array}{l}2-3 \% \text {; up to passage } \\
10\end{array}$ & WJ & 110 \\
\hline & $5 \% ; 5$ days & UCB & 112 \\
\hline & $5 \%$; up to 14 days & $A D$ & 103 \\
\hline & $5 \%$; up to passage 12 & WJ & 111 \\
\hline \multirow[t]{2}{*}{ No effect proliferation } & $1-3 \% ; 16 h$ & BM & 124 \\
\hline & $1 \%$; up to 33 days & BM & 115 \\
\hline \multirow[t]{3}{*}{ Higher population doublings } & $1 \% ; 2$ passage ( 8 days) & BM & 116 \\
\hline & $1 \%$; up to 52 days & BM & 115 \\
\hline & $1 \%$; up to 90 days & BM & 109 \\
\hline
\end{tabular}




\begin{tabular}{|c|c|c|c|}
\hline & $1 \%$; up to 350 days & BM & 24 \\
\hline & $3 \%$; up to 120 days & BM & 118 \\
\hline & $3 \%$; up to passage 22 & $A D$ & 11 \\
\hline & $5 \%$; up to 100 days & $A D$ & 102 \\
\hline & $5 \%$; up to passage 12 & WJ & 111 \\
\hline Increased number of CFU recovered & $1 \% ; 48 h$ & $A D$ & 99 \\
\hline & $1 \%$; 14 days & BM & 115 \\
\hline & $2 \% ; 14$ day & BM & 131 \\
\hline & $3 \% ; 14$ day & BM & 21 \\
\hline & $5 \% ; 14$ days & BM & 125 \\
\hline No significant alteration in CFU-F & $2 \%$; up to 21 days & $A D$ & 101 \\
\hline & $2 \%$; up to 21 days & BM & 25 \\
\hline Decreased number of CFU-F & $5 \%$; up to 21 days & BM & 25 \\
\hline
\end{tabular}

Table 6: The effect of hypoxia on hMSC genomic stability and expression. [Key to source of human Mesenchymal Stem Cells (hMSCs) column abbreviations: AD; Adipose tissue: BM; Bone Marrow: DP; Dental Pulp: WJ; Wharton’s Jelly: UC; Umbilical Cord: UCB; Umbilical Cord Blood: Other sources written in full).

\begin{tabular}{|l|l|c|c|}
\hline Effect of hypoxia & $\begin{array}{l}\text { Hypoxia conditions (\% } \\
\mathrm{O}_{2} \text { and duration) }\end{array}$ & $\begin{array}{c}\text { Source of } \\
\text { hMSC }\end{array}$ & Ref \\
\hline \multicolumn{2}{|c|}{ Genomic stability and profiling } \\
\hline $\begin{array}{l}\text { Enhancement of a genetic profile that maintains } \\
\text { the cells undifferentiated and multipotent }\end{array}$ & $1 \% ;$ up to 7 days & BM & 117 \\
\cline { 2 - 4 } & $1 \% ;$ up to 90 days & BM & 109 \\
\cline { 2 - 4 } & $5 \% ; 14 d$ & BM & 22 \\
\hline
\end{tabular}




\begin{tabular}{|c|c|c|c|}
\hline & $5 \% ; 24 h$ & $\mathrm{DP}$ & 126 \\
\hline $\begin{array}{l}\text { Partial genetic profile that maintains the cells } \\
\text { undifferentiated }\end{array}$ & $5 \% ; 24 h$ & DP & 126 \\
\hline \multirow[t]{5}{*}{ Telomere maintenance } & $\begin{array}{l}\text { 1\%; up to } 100 \\
\text { population doublings }\end{array}$ & BM & 130 \\
\hline & $2 \%$; up to 21 days & $A D$ & 101 \\
\hline & $2 \%$; up to passage 5 & $A D$ & 132 \\
\hline & $2 \%$; up to passage 5 & BM & 132 \\
\hline & $3 \%$; up to passage 15 & $A D$ & 11 \\
\hline Reduced DNA damage & $2 \%$; up to 21 days & $A D$ & 101 \\
\hline Chromosomal variability and instability & $5 \%$; up to passage 7 & BM & 133 \\
\hline $\begin{array}{l}\text { Reduced expression of tumor supressing genes } \\
\mathrm{p} 16, \mathrm{p} 21, \mathrm{p} 53 \text { and } \mathrm{pRb}\end{array}$ & $2 \%$; up to 21 days & $A D$ & 101 \\
\hline
\end{tabular}

Table 7: The influence of hypoxia on hMSC paracrine activity. [Key to source of human Mesenchymal Stem Cells (hMSCs) column abbreviations: AD; Adipose tissue: BM; Bone Marrow: DP; Dental Pulp: WJ; Wharton’s Jelly: UC; Umbilical Cord: UCB; Umbilical Cord Blood: Other sources written in full).

\begin{tabular}{|c|c|c|c|}
\hline Effect of hypoxia & $\begin{array}{l}\text { Hypoxia conditions (\% } \\
\mathrm{O}_{2} \text { and duration) }\end{array}$ & $\begin{array}{c}\text { Source of } \\
\text { hMSC }\end{array}$ & Ref \\
\hline \multicolumn{4}{|c|}{ Paracrine activity } \\
\hline \multirow[t]{6}{*}{ Increased release of growth factors } & $1 \% ; 24 h$ & BM & 134 \\
\hline & $1 \% ; 48 h$ & $A D$ & 122 \\
\hline & $1 \% ; 48 h$ & $A D$ & 99 \\
\hline & $1 \% ; 7$ days & BM & 117 \\
\hline & 1\%; 7 days & BM & 115 \\
\hline & $1 \% ; 7$ days & $A D$ & 129 \\
\hline
\end{tabular}




\begin{tabular}{|c|c|c|c|}
\hline & $2 \%$; up to 21 days & $A D$ & 101 \\
\hline & $3 \% ; 16 h$ & BM & 47 \\
\hline & $\begin{array}{l}3 \& 5 \% ; \text { up to passage } \\
5\end{array}$ & DP & 126 \\
\hline $\begin{array}{l}\text { Increased release of chemotactic and } \\
\text { angiogenic mediators }\end{array}$ & $0.1 \% ; 14$ days & BM & 135 \\
\hline $\begin{array}{l}\text { Decreased release of chemotactic and } \\
\text { angiogenic mediators }\end{array}$ & $5 \% ; 14$ days & BM & 135 \\
\hline $\begin{array}{l}\text { Increased release of } \\
\text { inflammatory/immunomodulatory mediators }\end{array}$ & $5 \%$; up to passage 5 & $\mathrm{DP}$ & 126 \\
\hline \multirow[t]{2}{*}{ Altered microRNA (miRNA) release } & $0-1 \% ; 12-24 h$ & BM & 136 \\
\hline & $2 \%$; 21 days & BM & 137 \\
\hline $\begin{array}{l}\text { Increased motility and vascularisation and/or } \\
\text { innervation of tissue }\end{array}$ & $1-3 \% ; 24 h$ & BM & 124 \\
\hline \multirow{2}{*}{$\begin{array}{l}\text { Increased and altered activity of ERK } \\
\text { pathway }\end{array}$} & $1 \%$; up to $24 \mathrm{~h}$ & BM & 104 \\
\hline & $1 \%$; up to $24 \mathrm{~h}$ & $A D$ & 129 \\
\hline $\begin{array}{l}\text { Increased release of angiogenic mediators } \\
\text { (altered secretome profile) }\end{array}$ & $1 \% ; 48 \mathrm{~h}$ & $A D$ & 98 \\
\hline
\end{tabular}

Table 8: The effect of chemical hypoxia, mediated by $\mathrm{CoCl}_{2}$ and DFO, on the "hMSC checklist” parameters.

\begin{tabular}{|c|c|c|c|}
\hline Effect of hypoxia & $\begin{array}{l}\text { Chemical Concentration } \\
\text { and duration }\end{array}$ & $\begin{array}{l}\text { Source of } \\
\text { MSC }\end{array}$ & Ref \\
\hline \multicolumn{4}{|c|}{ Cell morphology } \\
\hline \multirow[t]{2}{*}{ Altered cell morphology } & $\mathrm{CoCl}_{2}: 100 \mu \mathrm{M}$ for 4 days & UC & 146 \\
\hline & DFO: $120 \mu \mathrm{M}$ for 4 days & UC & 146 \\
\hline Unaltered cell morphology & $\begin{array}{l}\text { DFO: } 150 \mu \mathrm{M} \text { or } 400 \mu \mathrm{M} \\
\text { for } 48 \mathrm{~h}\end{array}$ & $A D$ & 147 \\
\hline
\end{tabular}




\begin{tabular}{|c|c|c|c|}
\hline \multicolumn{4}{|c|}{ Growth and proliferation } \\
\hline No effect on viability & $\mathrm{CoCl}_{2}: 100 \mu \mathrm{M}$ for $24 \mathrm{~h}$ & $\begin{array}{l}\text { Abdominal } \\
\text { aortic } \\
\text { aneurysm }\end{array}$ & 148 \\
\hline \multirow[t]{2}{*}{ Limited proliferation } & $\begin{array}{l}\mathrm{CoCl}_{2}: 50 \mu \mathrm{M} \text { or } 100 \mu \mathrm{M} \\
\text { up to } 72 \mathrm{~h}\end{array}$ & UC & 149 \\
\hline & $\begin{array}{l}\text { DFO: } 150 \mu \mathrm{M} \text { or } 400 \mu \mathrm{M} \\
\text { for } 48 \mathrm{~h}\end{array}$ & $A D$ & 147 \\
\hline \multirow[t]{3}{*}{ Decreased proliferation } & $\begin{array}{l}\mathrm{CoCl}_{2}: \text { up to } 100 \mu \mathrm{M} \text { up } \\
\text { to } 96 \mathrm{~h}\end{array}$ & UC & 146 \\
\hline & $\begin{array}{l}\mathrm{CoCl}_{2}: 500 \mu \mathrm{M} \text { for up to } \\
72 \mathrm{~h}\end{array}$ & $\begin{array}{l}\text { Abdominal } \\
\text { aortic } \\
\text { aneurysm }\end{array}$ & 148 \\
\hline & $\begin{array}{l}\text { DFO: up to } 120 \mu \mathrm{M} \text { up to } \\
96 \mathrm{~h}\end{array}$ & UC & 146 \\
\hline \multicolumn{4}{|c|}{ Differentiation potential } \\
\hline \multirow[t]{2}{*}{$\begin{array}{l}\text { Enhanced osteogenic differentiation } \\
\text { potential }\end{array}$} & $\begin{array}{l}\mathrm{CoCl}_{2}: 50 \mu \mathrm{M} \text { or } 100 \mu \mathrm{M} \\
\text { for } 10 \text { days }\end{array}$ & UC & 149 \\
\hline & $\begin{array}{l}\mathrm{CoCl}_{2}: 100 \mu \mathrm{M} \text { up to } 21 \\
\text { days }\end{array}$ & UC & 150 \\
\hline \multirow{2}{*}{$\begin{array}{l}\text { Decreased osteogenic differentiation } \\
\text { potential }\end{array}$} & $\mathrm{CoCl}_{2}: 100 \mu \mathrm{M}$ for 7 days & BM & 151 \\
\hline & $\begin{array}{l}\mathrm{CoCl}_{2}: 100 \mu \mathrm{M} \text { up to } 21 \\
\text { days }\end{array}$ & $A D, D P$ & 150 \\
\hline \multicolumn{4}{|c|}{ Attachment and Migration } \\
\hline \multirow[t]{2}{*}{ Higher migration rate } & DFO: $120 \mu \mathrm{M}$ for $24 \mathrm{~h}$ & $A D$ & 152 \\
\hline & DFO: $120 \mu \mathrm{M}$ for $24 \mathrm{~h}$ & BM & 153 \\
\hline \multirow[t]{3}{*}{ Increased expression of CXCR4 } & $\mathrm{CoCl}_{2}: 100 \mu \mathrm{M}$ for $24 \mathrm{~h}$ & $A D$ & 152 \\
\hline & DFO: $120 \mu \mathrm{M}$ for $24 \mathrm{~h}$ & $A D$ & 152 \\
\hline & DFO: $120 \mu \mathrm{M}$ for $24 \mathrm{~h}$ & BM & 153 \\
\hline Unaltered CXCR4 and CXCR7 expression & $\mathrm{CoCl}_{2}: 100 \mu \mathrm{M}$ up to $24 \mathrm{~h}$ & BM & 153 \\
\hline
\end{tabular}




\begin{tabular}{|c|c|c|c|}
\hline \multicolumn{4}{|c|}{ Paracrine activity } \\
\hline \multirow[t]{4}{*}{ Increased release of angiogenic mediators } & $\begin{array}{l}\mathrm{CoCl}_{2}: 50,100 \text { or } 150 \mu \mathrm{M} \\
\text { for } 7 \text { days }\end{array}$ & $\begin{array}{l}\text { Periosteum- } \\
\text { derived }\end{array}$ & 154 \\
\hline & $\begin{array}{l}\text { DFO: } 150 \mu \mathrm{M} \text { or } 400 \mu \mathrm{M} \\
\text { for } 48 \mathrm{~h}\end{array}$ & $A D$ & 147 \\
\hline & $\begin{array}{l}\text { DFO: } 15 \mu \mathrm{M}, 50 \mu \mathrm{M} \text { or } \\
100 \mu \mathrm{M} \text { up to } 5 \text { days }\end{array}$ & BM & 155 \\
\hline & $\begin{array}{l}\text { DFO: up to } 120 \mu \mathrm{M} \text { up to } \\
7 \text { days }\end{array}$ & $A D$ & 156 \\
\hline \multicolumn{4}{|c|}{ HIF-1 $\alpha$ regulation } \\
\hline \multirow[t]{6}{*}{ Up-regulation of HIF-1 $\alpha$} & $\mathrm{CoCl}_{2}: 250 \mu \mathrm{M}$ up to $24 \mathrm{~h}$ & BM & 136 \\
\hline & $\begin{array}{l}\mathrm{CoCl}_{2}: 50 \text { or } 100 \mu \mathrm{M} \text { for } \\
48 \mathrm{~h}\end{array}$ & BM & 151 \\
\hline & $\begin{array}{l}\mathrm{CoCl}_{2}: 100 \mu \mathrm{M} \text { for } 6 \text { to } \\
48 \mathrm{~h}\end{array}$ & $\mathrm{DP}, \mathrm{UC}$ & 150 \\
\hline & $\mathrm{CoCl}_{2}: 100 \mu \mathrm{M}$ for $72 \mathrm{~h}$ & BM & 157 \\
\hline & $\begin{array}{l}\text { DFO: up to } 120 \mu \mathrm{M} \text { for } \\
12 \mathrm{~h}\end{array}$ & $A D$ & 156 \\
\hline & $\begin{array}{l}\text { DFO: } 150 \mu \mathrm{M} \text { or } 400 \mu \mathrm{M} \\
\text { for } 48 \mathrm{~h}\end{array}$ & $A D$ & 147 \\
\hline No change in HIF-1 $\alpha$ & $\begin{array}{l}\mathrm{CoCl}_{2}: 100 \mu \mathrm{M} \text { for } 6 \text { to } \\
48 \mathrm{~h}\end{array}$ & $A D$ & 150 \\
\hline
\end{tabular}

Table 9: Genes that are reported to be regulated by HIFs in human MSCs (* designates a mixed species example (human/mouse)).

\begin{tabular}{|c|l|}
\hline & Reference \\
\hline Up regulated \\
\hline
\end{tabular}




\begin{tabular}{|l|l|}
\hline VEGF & $101,115,138,139$ \\
\hline HGF & 115 \\
\hline FGF & 100,115 \\
\hline MIF & 140 \\
\hline CHIP, Sox9 & 138 \\
\hline $\begin{array}{l}\text { CFD, Leptin, LPL, } \\
\text { PGAR }\end{array}$ & 113 \\
\hline Wnt10b & 116 \\
\hline G6PT & $141 *$ \\
\hline $\begin{array}{l}\text { HK1, HK2, PKM1, } \\
\text { PDK1 }\end{array}$ & 142 \\
\hline TWIST & 130 \\
\hline CXCL12 & 121 \\
\hline 3BP2, MT1-MMP & 143 \\
\hline Down regulated \\
\hline E2A, p21 & 142 \\
\hline RUNX2 & \\
\hline
\end{tabular}


